MISS LOIS JANE GREENFIELD (Orcid ID : 0000-0003-2323-8022)

\author{
Article type : Original Article
}

\title{
The 3D Facies Architecture and Petrophysical Properties of Hyaloclastite Delta Deposits: An Integrated Photogrammetry and Petrophysical Study from southern Iceland
}

Lois Greenfield ${ }^{1}$, John M. Millett ${ }^{1,2}$, John Howell ${ }^{1}$, Dougal A. Jerram ${ }^{3,4,5}$, Tim Watton ${ }^{6}$, Dave Healy ${ }^{1}$, Malcolm J. Hole ${ }^{1}$, Sverre Planke ${ }^{2,3}$

${ }^{1}$ Department of Geology \& Petroleum Geology, University of Aberdeen, AB24 3UE, Scotland

${ }^{2}$ Volcanic Basin Petroleum Research (VBPR), Oslo, Norway

${ }^{3}$ The Centre of Earth Evolution and Dynamics (CEED), University of Oslo, Norway

${ }^{4}$ DougalEARTH Ltd., Solihull, UK

${ }^{5}$ Visiting Fellow, Earth, Environmental and Biological Sciences, Queensland University of Technology, Brisbane, Queensland, Australia.

${ }^{6}$ Equinor, Stavanger, Norway

Corresponding author: Lois Greenfield, 11 Serald Street, Cruden Bay, Aberdeenshire, AB42 OHA, Scotland (loisgreenfield@rocketmail.com)

\section{Abstract}

Hyaloclastites develop where lava interacts with water resulting in deposits that have a unique and often complex range of petrophysical properties. A combination of eruptive style and emplacement environment dictates the size, geometry and distribution of different hyaloclastite facies and their associated primary physical properties such as porosity, permeability and velocity. To date, links between the $3 D$ facies variability within these systems and their petrophysical properties remain poorly understood. Hjörleifshöfði in southern Iceland presents an exceptional outcrop exposure of an emergent hyaloclastite sequence $>1 \mathrm{~km}$ wide by $>200 \mathrm{~m}$ high and enables an investigation of the distribution of the hyaloclastite deposits at seismic scale. Within this study we present a photogrammetry-based $3 D$ model from part of this recent hyaloclastite delta and incorporate previous work by Watton et al. (2013) to undertake detailed facies interpretation and quantification. Laboratory petrophysical analyses were performed on 34 core plugs cut from key field facies samples, including $P$ - and $S$-wave velocity, density, porosity and permeability at both ambient and confining pressure. Integration of the 3D model with the petrophysical data has enabled the production of pseudo-wireline logs and property distribution maps which demonstrate the variability of physical properties within hyaloclastite sequences at outcrop to seismic scale. Through comparison of our data with examples of older buried hyaloclastite sequences we demonstrate that the wide-ranging properties of young hyaloclastites

This article has been accepted for publication and undergone full peer review but has not been through the copyediting, typesetting, pagination and proofreading process, which may lead to differences between this version and the Version of Record. Please cite this article as doi: 10.1111/BRE.12415

This article is protected by copyright. All rights reserved 
become highly uniform in older sequences making their identification by remote geophysical methods for similar facies variations more challenging. Our study provides an improved understanding of the petrophysical property distribution within hyaloclastite sequences and forms a valuable step towards improving the understanding of similar subsurface sequences and their implications for imaging and fluid flow.

Keywords: lava delta, basalt, eruption, petrophysical distribution, fluid flow

\section{Introduction}

Hyaloclastite deltas comprise a significant contribution to the volcanic facies present at mid-ocean ridges, ocean islands and along volcanic rifted margins, especially those emplaced in the North Atlantic region (e.g. Planke et al., 2000; Jerram et al., 2009; Wright et al., 2012; Watton et al., 2014; Abdelmalak et al., 2016; Jerram et al., 2018). Such sequences reflect eruption of lava into water bodies of various depth (often 10s to 100s of meters), which provides valuable information about the palaeo-environments present during the onset and duration of volcanism (e.g. Skilling, 2002; Wright et al., 2012, Millett et al., 2015; Jerram et al., 2016 a \& b; Angkasa et al., 2017). The presence of such systems introduce a potential impact on how we interpret and understand the evolution of volcanic margins and associated flood basalt sequences (Abdelmalak et al., 2016; Planke et al., 2017). Hydrocarbon exploration is increasingly targeting systems in volcanic rifted margins that are host to significant volumes of basaltic hyaloclastite rocks within offshore areas, for example the Faroe-Shetland Basin (Jerram et al., 2009; Wright et al., 2012; Saetre et al., 2018), the Norwegian Margin (Abdelmalak et al., 2016), and offshore China (Sun \& Zhong, 2018). Understanding the role of hyaloclastite facies within these subsurface examples in the offshore realm can be challenging as they have to be accessed remotely through seismic or occasional borehole data, limiting the direct analysis and data collection about their 3D distribution in time and space. In addition, ongoing assessment of seismic imaging techniques and drilling for geothermal exploration also requires a robust understanding of the physical properties of hyaloclastites as a key component of prospective volcanic sequences (Santilano et al., 2015; Millett et al., 2018). Within volcanic deposits currently being explored for geothermal energy, the facies distribution and more specifically the porosity/permeability of the volcanic sequences are key parameters that will potentially enhance or retard fluid flow. As such, it is valuable to understand the location and distribution of fragmented volcanics such as hyaloclastites vs lava flows. The effects that internal heterogeneities, rock properties and diagenetic evolution have on the geophysical properties of analogue volcanic sequences remain relatively poorly understood (e.g. Watton et al., 2013), but are important if we are to make more accurate correlations between known onshore examples and those imaged or sampled in the subsurface.

Whereas much is already known about the general properties of Icelandic hyaloclastites (e.g. Frolova et al., 2005; Franzson et al., 2010), no studies have analysed the distribution of rock physical properties relative to the complex 3D architecture that has been observed in outcrop examples (e.g. Watton et al., 2013). Seismic imaging within and beneath basaltic rock facies is also problematic due to their often-high density, velocity and heterogeneity which promotes significant attenuation and scattering (e.g. sub-basalt imaging problem, Fitzgerald \& Bean, 2001). Hyaloclastites commonly form thick units towards the base and sometimes higher within thick volcanic sequences and may display significant internal heterogeneity (e.g. Jerram et al., 2009; Millet et al., 2015; Angkasa et al., 2017). In 
some cases, spectacular inclined stratal packages within hyaloclastite deltas (10s to $100 \mathrm{~s}$ of meters thick) are well imaged in seismic sections, however, in other cases they may appear more transparent, chaotic and less well defined, even in the same seismic dataset (Planke et al., 2000; Wright et al., 2012; Abdelmalak et al., 2016). An improved understanding of the natural variations in petrophysical properties and their distributions is required in order to better understand the causes and implications of these differences. Additionally, drilling through thick heterogeneous volcaniclastic successions has proven to commonly entail expensive drilling challenges and therefore improved understanding of their rock properties and their distribution may be key for improving drilling efficiency and success rates (Millett et al., 2016). Finally, the alteration of glassy mafic rocks consumes $\mathrm{CO}_{2}$, so basaltic sequences have been proven to form viable avenues for $\mathrm{CO}_{2}$ disposal (Matter et al., 2009; Jones et al., 2016). For all of the reasons above, improved understanding of hyaloclastite reservoir properties and their distribution (e.g. Thien et al., 2015) is an important area where new data are needed.

In this contribution we examine the hyaloclastite facies properties of an $800 \mathrm{ka}$ emergent volcano succession at Hjörleifshöfði (Watton et al., 2013), which forms a small Quaternary outlier on the Mýrdalssandur outwash plain around $10 \mathrm{~km}$ east of Vik in southern Iceland (Figure 1). We provide a review of what is already known about hyaloclastites before we expand and present our data. Through detailed mapping combined with laboratory petrophysical testing for porosity, permeability, P-wave Velocity (Vp), S-wave Velocity (Vs), and density on selected field samples, the distribution of physical properties within the system has been mapped out. Our results demonstrate a very wide range of physical properties for the young hyaloclastite deposits at Hjörleifshöfði and suggest clear linkages between primary facies variations and architecture. The studied facies all exhibit generally high porosity and permeability and suggest that the system remains open and connected in its present subaerial environment. Due to the instability of the dominant volcanic glass components of the sequence, this open nature appears likely to result in rapid and pervasive alteration and porosity occlusion during burial diagenesis, a process that will be accentuated by the mechanically weak nature of the rocks. By comparison with older examples of similar facies, we suggest that hyaloclastite facies will undergo a relatively rapid transition from having good reservoir properties through to becoming seals during burial. Understanding where a particular subsurface example is positioned in reference to these dynamic processes is key for building improved fluid flow predictions in various settings going forward.

\section{Hyaloclastite deposits}

Hyaloclastites are formed by the fragmentation of lava by rapid quenching on contact with water or ice (e.g. Watton et al., 2013 and references therein). Common components include sideromelane glass, tachylyte, glassy lava fragments and secondary altered clays (smectite, palagonite etc.). The term hyaloclastite has been used widely in the literature to describe a variety of brecciated lava deposits, including volcanic slope breccia (e.g. Moore et al., 1973; Tribble 1991), quenching by injection into wet sediments (e.g. Hanson \& Schweickert, 1982), interstitial pillowmatrix (e.g. Furnes et al., 2003), and ice-confined (sub-glacial) hyaloclastite ridges (e.g. Tuffen, 2007). The broad definition covers a diverse range of primary-fragmented to reworked volcanic to volcano-sedimentary facies (e.g. Watton et al., 2013), and therefore brings an equally broad range of rock properties. Hyaloclastite deposits can comprise a huge diversity of facies incorporating grain sizes from clay dominated through to pillows (boulder equivalent), and even coherent lava-like subaqueous sheet flows (e.g. Skilling, 2002). The distribution of different 
facies in three dimensions will help determine the physical properties of any given sequence and in turn will dictate the geophysical response of remote sensing techniques that are sensitive to porosity and permeability variations (e.g. borehole and seismic measurements). Where hyaloclastites are associated with subsurface exploration targets, for example petroleum exploration, geothermal energy or $\mathrm{CO}_{2}$ sequestration, improvements in our understanding of both the range and distribution of physical properties in different settings is key for improving subsurface interpretation.

There are two main types of environments where hyaloclastites form a major rock component; emergent volcanoes (e.g. Cole et al., 2001) and as lava fed deltas (e.g. Hawaiian lava flows, Tribble, 1991; Mattox \& Mangan, 1997). In some instances, one environment leads to another, such that an emergent volcano will then erupt lavas that feed a delta. Lava deltas are commonly formed by the accumulation of sheet or lobe-like hyaloclastite breccias that form when lava enters into water from a subaerial environment (Fuller, 1931; Moore et al., 1973; Skilling, 2002; Jerram et al., 2009; Wright et al., 2012; Stevenson et al., 2012). Analogous examples of hyaloclastite deltas are widely observed in Antarctica (e.g. Johnson \& Smellie, 2007), Hawaii (Lipman \& Moore, 1996; Skilling, 2002; Watton et al., 2014), Iceland (Furnes \& Fridleifsson, 1974; Watton et al., 2013), Greenland (Pedersen et al., 2002), offshore in the Faroe-Shetland Basin (Jerram et al., 2009; Wright et al., 2012; Millett et al., 2015) and offshore on the Norwegian margin (e.g. Abdelmalak et al., 2016; Planke et al., 2017). Lavas erupted from initially subaqueous settings that become emergent, e.g. Surtseyan types, will reflect this transition within their internal facies (e.g. Watton et al., 2013), and those under ice will differ yet again due to the potentially restricted nature of the confining ice and associated water (e.g. Smellie \& Hole, 1997).

Eruptive processes and particle propagation mechanisms differ between subaqueous and subaerial originating eruptions; each setting will produce a distinct end-member of hyaloclastite breccia. Eruptions that occur initially as submarine and later evolve to subaerial became known as "Surtseyan" after the formation of Surtsey Island off the southern coast of Iceland in the 1960s (Walker, 1971). The term has been used by others to describe the character of the volcanic and hyaloclastite deposits that are produced by explosive hydromagmatic activity. The various explosive hydromagmatic processes that occur during the transition from submarine to subaerial eruptions control the supply and distribution of hyaloclastite material and influence the overall character of the delta (Watton et al., 2013). While progress has been made to describe and characterise the main facies types that we see within thick hyaloclastite deposits, a robust understanding of how such variations affect the facies associations and in particular their resultant rock properties is somewhat limited (e.g. Watton et al., 2013), and forms the main focus of the present study.

\section{Methods}

\subsection{Digital Outcrop Reconstruction}

A key aspect of this study was the utilisation of recent advances in digital outcrop mapping (McCaffrey et al., 2005) to produce a detailed 3D model of the hyaloclastite sequence at Hjörleifshöfði. Although there has been relatively wide use of such $3 \mathrm{D}$ geological models to address sedimentological and structural questions (e.g. Buckley et al., 2008; Enge et al., 2010; Labourdette \& Jones, 2007; Vollgger \& Cruden, 2016), they have not been as widely used for volcanologic and igneous problems, with some exceptions (e.g. Nelson et al., 2011; James \& Varley 2012; Vosgerau et al., 2016; Eide et al., 2017;). To characterise the Hjörleifshöfði delta architecture, a series of groundbased geo-oriented photographs were taken along the southern cliff section (with c. $70 \%$ overlap and two 
perspectives at each position) in order to construct a 3D surface model. The position of the cliff transect curves around the south western corner of the Hjörleifshöfði outlier, and was chosen in order to provide both a cross-sectional and broadly frontal perspective of the emergent volcanic sequence. An overview of the workflow used to generate the scaled digital outcrop model in Agisoft software, and the final result is provided in the supplementary section (Supplementary figures $1 \& 2$ ). The final 3D outcrop model consists of a real colour 3D surface generated from a point cloud with c. 16.4 million xyz coordinates at an effective resolution of c. $13 \mathrm{~cm}^{2}$ per pixel. The scaled model is $1910 \mathrm{~m}$ long and $180 \mathrm{~m}$ high at the tallest cliff, therefore providing a robust field example to bridge the gap between outcrop and seismic scale. The vertical surface of the reconstruction provides virtual access to all of the outcrop for mapping and interpretation of the facies present, which is particularly useful given the vertical scale and limited access to the higher portions of the outcrop.

\subsection{Digital Outcrop Interpretation}

The digital outcrop model was imported into LIME to enable interpretation (Buckley et al., 2018). LIME provides a simple to use yet effective interpretation tool whereby statistical measurements such as bed thickness, dip and strike of beds, faults etc. can all be measured directly from the virtual 3D outcrop. A summary of the process followed to interpret and manipulate the 3D geological model is provided in the supplementary section (Supplementary figure 1b). Previous field observations were used to constrain micro-detail such as clast composition and sub-bedding scale features (see Watton et al., 2013) of key facies that are otherwise below the model resolution with the interpreted lithological relationships discussed further in Section 4. Each rock package was initially identified based on the lateral continuity of bounding surfaces and overall bedding structure along the section. The geometry of stratigraphical terminations, e.g. truncation of bedding planes and onlap/offlap relationships were used to establish the position of the main bounding surfaces.

\subsection{Petrophysical data}

During fieldwork in 2015, a selection of large c. 2-5 kg samples were collected from the Hjörleifshöfði outlier in order to collect representative examples of the facies defined by Watton et al. (2013) for later petrophysical testing. Details of the sample locations are presented in the online supplementary data. Samples were collected from in-situ outcrops by hammer and chisel where accessible but were also collected from slumped rock masses where facies were inaccessible. Care was taken to avoid any visible damage or fracturing during sampling, however, as with any field-based sampling, minor non-visible micro-fractures cannot be fully excluded. Petrophysical measurements including density, P-wave velocity, S-wave velocity, porosity and permeability were performed on a total of 34 dry core plugs at the University of Aberdeen (supplementary data). Testing was undertaken on c. $2.55 \mathrm{~cm}$ diameter core plugs cut from larger field samples to a length of c. $5.11 \mathrm{~cm}$ or shorter. In general, the hyaloclastite facies proved challenging to core due to the weak nature of the samples. P-wave velocity was measured using a JSR Ultrasonic pulser/receiver DPR 300 and an oscillator recorder. The receiver was set using a $35 \mathrm{MHz}$ signal with low pass and high pass filter $3.00 \mathrm{MHz}$ and $0.0 \mathrm{MHz}$ respectively. The pulser was set up under $900 \mathrm{v}$ and $100 \mathrm{~Hz}$ PRF with energy pulse of $81.0 \mathrm{~mJ}$. Porosity and density were measured on a helium injection porosimeter along with high precision (averages of 10 calliper measurements of core diameter and length to $0.01 \mathrm{~mm}$ accuracy) core plug volume 
measurements (Farrell et al., 2014). Klinkenberg corrected (Klinkenberg, 1941) single phase permeability was measured along the axial direction of core plugs using nitrogen $\left(\mathrm{N}_{2}\right)$ gas as the pore fluid in a permeameter with a Hassler sleeve pressurised to $400 \mathrm{psi}$ to avoid gas leakage around the sides of the core (e.g. Farrell et al., 2014).

Permeability tests were also performed on 4 core plugs using the steady-state flow method at confining pressures between 10 and $120 \mathrm{MPa}$ using the same apparatus and methods as Farrell et al. (2014). These samples represent facies that were originally defined by Watton et al., 2013 and are outside of the extent of our modelled section; more detail is provided in section 4.1.6. In the confining pressure permeameter, core plugs were wrapped in heat shrink polyolefin tubing and confined in a pressure vessel by oil pressurised using a hand pump. A five-minute interval was left after each increase in confining pressure before permeability was measured, to allow equilibration of the sample.

\subsection{Property distribution maps and pseudo-logs}

By integrating the new and existing petrophysical and lithological data with the interpreted 3D outcrop model, representative property distribution maps were compiled for the Hjörleifshöfði sequence. From these property maps, hypothetical borehole locations were chosen from which to compile pseudo-wireline logs through the sequence (e.g. Angkasa et al., 2017). Additional inferences from real borehole studies in similar settings (e.g. Hawaii and the Faroe Islands; Watton et al., 2014; Nelson et al., 2009) were also used to inform the likely log signatures through the chosen localities. The compiled property maps and pseudo-wireline logs form a valuable way of populating constrained physical properties of volcanic sequences in the third dimension and give valuable insights into the likely geophysical responses of this and similar sequences. Within this study we have refrained from moving on to quantitative synthetic seismic modelling, due to constraints in the volume and coverage of data, however, the study clearly demonstrates the potential for such modelling with improved sample coverage and core recovery.

\section{Geological Model \\ 4.13D outcrop model}

In order to map out the main facies variations within the 3D model, a litho-stratigraphic description of the main units has been used. This is largely based on the initial field work by Watton et al. (2013), with additional quantitative (e.g. bedding dips) and petrophysical information gathered during the present study. Figure $1 \mathrm{~b} \& \mathrm{c}$ provide a modification of the facies model presented by Watton et al., 2013. We have simplified the diagrams into the four categories according to the main phases that range from the initial onset of subaqueous eruption to emergence (and reworking), to subaerial effusion. A description of the main facies units covered by our digital model (Table 1) and their depositional environments are given below, along with a brief description of additional sampled facies from the Hjörleifshöfði sequence that fall outside of the 3D model. For consistency we have used the same facies codes and terminology as Watton et al. (2013). Observations and interpretations are summarised in table 1.

\subsubsection{Massive Breccia (VB)}

Lithofacies VB (Massive Breccia) forms the basal component of the southern-most exposure at Hjörleifshöfði and features a $\sim 75 \mathrm{~m}$ thick package of facies VB, consisting of thick (c. $10 \mathrm{~m}$ ) matrix supported 
volcanic breccia beds that generally lack evidence of notable internal bedding structures. Fieldwork by Watton et al., 2013 defines the VB unit to consist of a series of poorly sorted breccia, suspended in a poorly sorted matrix, often with evidence of inverse grading where bedding is seen. A range of randomly orientated angular clast sizes from fine grained sand up to clasts $80 \mathrm{~cm}$ diameter are common throughout VB and vary in composition from non-vesicular basalt to vesicular basalt, pillow fragments and tephra (Watton et al. 2013, Table 1). The matrix consists of fragmented and poorly sorted, coarse grained to small pebbles of deeply altered glass and crystalline basalt, cemented by palagonite and secondary calcite and zeolite which partially fill the porosity. The bedding dips range between 5 $15^{\circ} \mathrm{SE}$ and show a crudely steepening trend further up-sequence (Figure 4). Contacts between the main bedding planes are undulose and typically erosive, evidenced by scouring and truncation of underlying beds.

The deposits of VB are interpreted to represent episodic high-density grain flow deposits originating from remobilization of hydromagmatic deposits formed during early Surtseyan style subaqueous volcanism (e.g. White, 2000). The episodic supply of new eruption material to the flank of the eruption site coupled with the mechanical instability of submarine slope deposits (Schiffman et al., 2006) would have likely contributed to periodic collapses initiating mass gravity transport events which flowed down the palaeo-slope. The debris flows were deposited on an initial slope that had a shallow dip angle $\left(<20^{\circ} \mathrm{S}\right)$ and the low textural and compositional maturity of the sequence suggests a relatively close proximity to the volcanic source. The sequence is interpreted to reflect a broadly southward progradation of the delta down a subaqueous slope.

\subsubsection{Planar bedded hyaloclastite breccia (HBp)}

Lithofacies HBp (planar bedded hyaloclastite breccia) was deposited on top of and adjacent to the VB facies (Figure $2 \mathrm{~b} \&$ Box E). Composition of the constituents of HBp is similar to that of VB, the main difference being that bedding is more organised into sub-meter scale planar and wavy bedding and commonly grade up according to grain size. Meter scale sandy waveforms are more common at the top of the sequence, with less occurrences of large fragmented clasts. There are large channel structures observed in facies HBp that have a stacked architecture within the outcrop in the vicinity of fault B on the eastern hanging wall. The channels are filled with clast supported hyaloclastite fragments, in some cases exceeding $1 \mathrm{~m}$ diameter (Figure $2 \mathrm{~b}$ ).

HBp represents continued sustained debris flows originating from the evolving pillow breccia complex upslope, but in contrast to VB, it is a lower energy system. The planar low angle foreset beds are considerably thinner than facies VB and show regular interludes of lower energy sand to granular flows representing reworking during periods of reduced material supply. These gravity flows were still capable of transporting small boulders, although the magnitude of such events was significantly less than that of facies VB, inferred by the presence of obvious bedding planes and smaller range of clast sizes. The channels visible in facies HBp are best developed in a fallen block associated with a listric fault scarp (Figure 2b, east of fault B) suggesting that faulting may have contributed to erosion and remobilisation of sediments. The channels are filled with matrix supported hyaloclastite material and large $(\sim 1 \mathrm{~m})$ angular basalt clasts indicative of water erosion and uni-directional fluid transport taking place in between pulses of volcanic activity.

4.1.3 Imbricated cross bedded hyaloclastite breccia (GHip) 
Lithofacies GHip (imbricated cross bedded hyaloclastite breccia) overlies an unconformity surface that cuts down into the underlying HBp facies (Figure $2 b \&$ Boxes $\mathrm{C} \& \mathrm{E}$; Figure 3e). The unconformity is onlapped by hyaloclastite breccia facies (GHip), characterised by a package of inclined imbricated cross-beds., The sequence is typically around $30 \mathrm{~m}$ thick, but increases to c. $90 \mathrm{~m}$ deep in the south eastern part of the delta. Watton et al. (2013) observe clast sizes to range from small $(2-10 \mathrm{~cm})$ to larger boulder sized basalt fragments $(80 \mathrm{~cm})$ that are encased in a matrix of medium to coarse granular, moderately to well sorted sideromelane glass and vesiculated tephra (commonly $<1 \mathrm{~cm}$ grain size). The imbricated cross beds range between 4 and $10 \mathrm{~m}$ thick and frequently fine up from coarse grained with boulders to sandy beds of angular sideromelane clasts. However, occasionally inverse grading is noted to occur within the GHip unit (see figure 11, lithological logs from Watton et al., 2013). Geochemical analysis was used by Watton et al. (2013) to associate this unit with subaerial lava flows that occur towards the inferred feeder vent, north of the outcrop. Major slumping affects the sequence of the west side of the modelled exposure (Figure $2 b$ \& Box G) and is discussed below.

The unconformity that truncates the bedding of HBp and the on-lapping relationship of GHip suggest that there was a time of non-deposition and erosion prior to the deposition of GHip. Clinoforms are observed to drape the truncated surface of HBp at an initial angle of c. $25^{\circ}$ before shallowing to c. $15^{\circ}, 40 \mathrm{~m}$ up-section (Figure 3e; Figure 4) demonstrating the influence of the eroded and scoured topography of HBp on subsequent deposition. Deposition of GHip is interpreted to represent a change to a shallower, higher energy setting as the delta continued to build up and fill accommodation. The constituents of facies GHip are noted to have a compositional and morphological similarity to the incised channel fill observed in facies HBp. GHip is interpreted to represent the unconfined equivalent to the hyaloclastite channel facies observed to incise facies HBp. The GHip facies is interpreted to be the result of reworking of both juvenile and remobilized volcanic material derived from the flanks of the evolving surtseyan volcano in a shallow marine to tidal setting.

\subsubsection{Trough cross-bedded volcaniclastic sandstone/breccia (VStcb)}

Lithofacies VStcb (Trough cross-bedded volcaniclastic sandstone/breccia) caps the sequence covered by our model. It consists of a thin $(<10 \mathrm{~m})$ veneer of matrix supported trough cross-bedded coarse grained hyaloclastite (VStcb) that onlaps the unconformity surface that cuts facies GHip (Figure 2, Box D). The hummocky erosional topographical surface of GHip exerts a significant influence on the depositional regime of the reworked volcanic sandstone above and appears to have led to the omni-directional trough cross-bedded character.

VStcb reveals a mixed volcaniclastic assemblage comprising primary tephra and mixed epiclastic material eroded from an exposed lava plateau and is interpreted to represent a shore-proximal reworked deposit likely above palaeo-wave-base on the flanks of the emerging Surtseyan edifice. High energy reworking of mixed juvenile hydrovolcanic clasts and tephra led to the improved sorting and some mechanical rounding of clasts within this facies. Whether the edifice emergence at this location is related simply to Surtseyan build up, or if relative base level changes also occurred is hard to delineate, however, the presence of the erosive unconformity beneath the onset of VStcb facies may suggest a preceding period of relative uplift.

\subsubsection{Structural and intrusive features}


Within facies VB, a saucer-shaped sill intrusion is identified (Figure 2b \& Box F; Figure 3a \& b). The flat base of the intrusion has a concordant relationship with the host bedding planes, but the tips have an inclined discordance to the host stratigraphy to form a concave-up geometry that cuts through the beds. The intrusion propagates across the bedding along an inclined angle of $\sim 50^{\circ}$ and ascends $15 \mathrm{~m}$ through the stratigraphy before pinching out. The upper margin of the intrusion is sharp but irregular and the lower margin appears somewhat diffuse whilst the internal fabric has a brecciated and chaotic appearance.

Emplacement is interpreted to have occurred into partially consolidated strata (e.g. Thomson \& Schofield, 2008; Schofield et al., 2012), and followed by a period of rapid cooling perhaps aided by convective heat dissipation in the initially high permeability host rock facies (e.g. Iyer et al., 2017). The irregular and chaotic fracture patterns within the sill demonstrate potentially rapid cooling and could therefore indicate quenching in the presence of groundwater during emplacement. No evidence for fluid-fluid mingling between the juvenile magma of the sill and the surrounding sediments during emplacement has been seen at the resolution of our model.

Listric style normal faulting is observed to bisect the volcanic debris sequence with an estimated displacement of at least $50 \mathrm{~m}$, so that facies HBp is positioned adjacent to the older strata of VB (Figure 2b, faults A $\&$ B; Figure $3 \mathrm{~d}$ ). The faults dip between $20-50^{\circ}$ and are steeper at the top before shallowing with depth. On the eastern blocks of the faults, the sediments of HBp drape and thin across the thresholds of the faults, which is interpreted as syn-sedimentary faulting close to the surface. The sediments of the footwall block of fault A are obscured by homogenisation of sedimentary structures in a damage zone $>20 \mathrm{~m}$ wide. High angle $\left(\sim 80^{\circ}\right)$ normal faults $\mathrm{C}$ and $\mathrm{D}$ post-date the large listric faults. Combined offset on the faults is estimated to be at least $100 \mathrm{~m}(60 \mathrm{~m}$ on fault $\mathrm{C}$ and $40 \mathrm{~m}$ on fault D).

A major slump (Figure $2 \mathrm{~b} \&$ Box $\mathrm{G}$ ) is present in the SW portion of the cross section and is measured to have a limb dip of around $35^{\circ}$, a wavelength of $\sim 200 \mathrm{~m}$ and an amplitude of $\sim 75 \mathrm{~m}$. Parasitic folds are observed to occur in some layers, whereas most layers remain un-deformed or are instead offset by small normal faults (Figure 3c). Although there doesn't appear to be a relationship between bed composition and the mode of deformation, generally speaking there is a theme of small-scale brittle dislocation. It is noted that there appears to be no evidence of soft sediment fluidization (e.g. sand injectites) between beds of varying density.

The slump structures visible on the northwest section of the model give evidence for syn-sedimentary deformation and delta collapse. They are interpreted to represent possible triggers for mass sediment transport events and therefore contributed to the high energy depositional character of facies GHip (Figure $2 \&$ Table 1). The contrast in strength between beds of clast-poor (sand rich) and clast-rich deposits is complex and may be related to sorting, clast size, clast shapes, grain strength and degree of alteration. However, at Hjörleifshöfði, it appears that both fine and coarse layers are deformed along certain zones, suggesting far-field stress, rather than small scale local rheology variations caused the localising of deformation. It is thought that the faulting is a result of the same wider stress regime and deformation occurred in response to a phased gravity-driven slump of part of the semi-lithified edifice (after Alsop \& Marco, 2013) in the shallow subsurface.

\subsubsection{Additional volcanic facies outside the $3 D$ model extent}


The primary focus of this study is the $3 \mathrm{D}$ transect model which incorporates the main facies as described above. However, a small number of additional facies characterized by Watton et al. (2013) from the Hjörleifshöfði complex occur outside the extent of the 3D model and were also sampled during this study. These analyses will be presented in the petrophysical section below as they give valuable additional petrophysical constraints for facies within this setting. These include 1) columnar lava interior $c L$ (Figure 5a), 2) pillow breccia complex $h P$ (Figure 5b), 3) tephra and quench lapilli FA (Figure 5c) and 4) a newly identified clastogenic lava facies (Figure 5a), codes in italics indicate the facies code defined by Watton et al., 2013. Figure 5 displays field examples of these facies, all of which are described by Watton et al. except the clastogenic lava facies which comprises a columnar lava unit that is entirely made from welded glassy angular to irregular lapilli and bombs. This unit is interpreted to include partially rehomogenized tephra, from a very proximal vent that maintained enough collective heat upon accumulation to cool as an individual unit, hence the through-going cooling joints.

\subsubsection{Summary of key facies relationships}

In Figure 6, a simplified model is presented to summarise the main evolutionary stages of the emergent Hjörleifshöfði hyaloclastite delta, modified after Watton et al. (2013). The eroded deposits of VB are draped by the syn-sedimentary deposits of HBp and represent high density grain flow deposits formed by major collapse events originating from the early subaqueous edifice building deposits erupted onto a shallow angle shelf to the north (Figure 6a). After a period of non-deposition and erosion, the beds of GHip were deposited to onlap HBp initially at high angles, but their inclination gradually shallow upwards as the topographical lows caused by erosion were filled up. GHip is interpreted to represent high energy prograding density currents reworking detritus from the emerging Surtseyan volcano to the north into a shallow marine shelf up to wave-base setting (Figure 6b). An erosional unconformity surface cuts into the GHip facies indicating a depositional hiatus at this time. VStcb drapes the eroded surface of GHip and indicates a change to a shallow water environment with high energy wave reworking on the flanks of the emergent Surtseyan edifice to the north (Figure 6c). Subaerial to transitional facies including lava flows, tephra and quench lapilli along with the welded clastogenic lava facies become dominant during emergence and buildup phases of edifice growth. Evidence for syn-depositional faulting and major slumping is demonstrated at a number of locations along the 3D model section and signifies the highly unstable nature of the edifice during its accumulation.

\section{Petrophysics}

Within this section, the petrophysical properties of selected field samples from the Hjörleifshöfði sequence are presented. All petrophysical results are summarised in Table 2. For clarity, samples from large dense clasts comprising glassy to crystalline basalt, have been presented as groups separate from their encasing facies matrix due to their entirely different bulk properties at the core plug scale. Full analysis, including the additional facies samples described above, can be found in the online supplementary data.

\subsection{Porosity distribution}

The very high porosities of some of the analysed hyaloclastite facies in this study exceed those generally regarded as 'critical porosity' c. 40 \% for sedimentary rocks (e.g. Nur et al., 1998), with the samples in the range of 
40-49\% porosity still maintaining calculated bulk moduli of 1-2 GPa. These particular samples are extremely fresh with angular and irregular grains, with some of the coarser examples also containing clasts with visible intra-clast porosity (Figure 7). The high permeability of these fresh samples is interpreted to be due to the angular to irregular nature of the majority of the grains. Within the coarser examples there is the added contribution from the abundant intra-clast vesicular porosities observed in the coarser grained facies (e.g. Figure 7) which can also act to increase the porosity for a given macro grain size distribution. In addition, connectivity between vesicles may be increased by microfractures which would further increase permeability for a given observed porosity. The highest recorded porosities from the Hjörleifshöfði samples are consistent with, if not slightly higher than, the highest recorded hyaloclastite primary porosities prior to the onset of incipient alteration (below c. $1 \mathrm{~km}$ burial) from the HSDP drilling program on Hawaii (Walton and Schiffman, 2003). Samples of variably altered hyaloclastite from Iceland (Frovlova et al., 2005) show a similar range to this study, but with even higher porosities for some of the freshest samples. One key difference from this study is the higher permeability of samples of around $30 \%$ porosity as discussed above, suggesting that these higher values of permeability at lower porosity relate to pore structure and not to variable alteration, which is the main control in the samples studied by Frovlova et al. (2005). Limited facies information is available in the Frovlova study precluding more detailed comparisons.

\subsection{Ambient pressure data}

The samples display a wide range of velocities with Vp c. 1.2-6.4 km/s, Vs c. $0.7-3.2 \mathrm{~km} / \mathrm{s}$ and Vp/Vs ratios from 1.3-2.2. Within this range there are two broad groupings, comprising Group 1 (Figure 8, open symbols): the hyaloclastite matrix and lapilli tuff samples (Vp 1.2-3.9 km/s; Vs 0.7-2.8 km/s; Vp/Vs 1.3-2.2) and Group 2 (Figure 8 , filled symbols): the columnar and clastogenic lava flow cores along with the intra-hyaloclastite pillow core and basaltic blocks (Vp 3.9-6.4 km/s; Vs 2.2-3.2 km/s; Vp/Vs 1.5-2.1) (Figure 8). The dry bulk density of the samples ranges from 1.1-3 g/ $\mathrm{cm}^{3}$ whilst the grain density ranges from 2.2-3.3 $\mathrm{g} / \mathrm{cm}^{3}$. Within these ranges the two groups are again broadly separated but with much greater overlap; Group 1: bulk density $1.1-2.3 \mathrm{~g} / \mathrm{cm}^{3}$ and grain density $2.2-3.3$ $\mathrm{g} / \mathrm{cm}^{3}$, and Group 2: bulk density $2.6-3 \mathrm{~g} / \mathrm{cm}^{3}$ and grain density 3-3.3 g/ $\mathrm{cm}^{3}$ (Figure 8, filled symbols). By comparing the $\mathrm{Vp}$ versus density relationship for the separate groups, the samples from both groups plot closely around the relationship derived by Bartetzko et al. (2005) for a global database of scientific borehole data from well penetrations through mafic LIP deposits.

The average $\mathrm{Vp} / \mathrm{Vs}$ ratio for the samples is c. 1.68 with the hyaloclastite group showing slightly lower $\mathrm{Vp} / \mathrm{Vs}$ of 1.68 compared to 1.72 for the dense crystalline facies (Figure 8). These values are slightly lower than reported e.g. from the southeast Greenland margin (Vp/Vs 1.8-2, Planke and Cambray 1998) and for the Lopra 1/1A borehole on the Faroe Islands (Vp/Vs c. 1.8, Petersen et al., 2013), however, the unsaturated nature of the testing and the significant variations in porosity within the sample suite restricts direct comparisons. The grain density appears to be fairly uniform between Vp velocities of c. 3.5-6.3 supporting a broadly similar basaltic composition bulk end-member for the volcanism within the sampled intervals. Deviations towards lower grain density is the generally expected pathway for alteration of basaltic constituents, due to the majority of alteration reactions forming larger molecular structures e.g. palagonite, clays and or zeolites (Neuhoff et al., 2000; Stroncik and Schmincke, 2002; Thien et al., 2015).

This article is protected by copyright. All rights reserved 
The permeability and connected porosity of the Hjörleifshöfði samples varies over a very large range from c. 2-49 \% porosity and over seven orders of magnitude of permeability, from 0.0005 to 8784 millidarcies (mD) (Figure 8). The broad groups also show wide internal ranges with Group 1 displaying generally higher porosity (20-49 \%) and permeability (15-8784 mD) compared to Group 2, which displays generally very low porosity of 2-17\% and permeability of 0.0005-82 $\mathrm{mD}$ (Figure 8 ).

Of the three hyaloclastite matrix sample suites, facies VB and GHip display good groupings, each around c. $4000 \mathrm{mD}$ but with the latter displaying higher porosities (39-49\%) compared to VB (32-34 \%). Facies HBp is observed to be more altered and clay rich in thin section (Figure 7) and displays a much wider spread of data with lower porosities (20-27\%) and variable permeability ranging from 15 to $8784 \mathrm{mD}$ (Figure 8 ). It appears clear that the relatively less altered hyaloclastite facies VB and GHip, even with on average poorer sorting, have a relatively high potential for fluid flow prior to the onset of significant alteration which appears to have preferentially affected facies HBp within the analysed samples.

The more structureless facies of Group 2 also display significant internal variations in porosity and permeability. All of the massive crystalline to glassy crystalline samples reveal negligible permeability $(<0.01 \mathrm{mD})$ and generally lower porosity $(<10 \%)$ (Figure 8 ). The clastogenic lava samples, on the other hand, display consistently higher permeability (just under $100 \mathrm{mD}$ ), five orders of magnitude higher than the columnar lava flow core which appears almost identical in the field. The tephra and quench lapilli matrix between the two columnar facies (Figure 5b) plot with 47 and $1144 \mathrm{mD}$ suggesting flow potential (albeit a large range and only two samples) (Figure 8). A sample from one of the zoned bombs in the same facies also displays elevated flow potential of $0.26-28 \mathrm{mD}$, compared to the more massive samples, representing the gradation from the core to the more vesicular glassy margins.

\subsection{Confining pressure permeability experiments}

To gain further insight into the permeability evolution of the Hjörleifshöfði hyaloclastite samples during burial, variable confining pressure (hydrostatic $\sigma \mathrm{v}=\sigma \mathrm{h}=\sigma \mathrm{H}$ ) permeability tests were undertaken to try and constrain the possible effects of mechanical compaction on fluid flow during burial. It should be clearly stated that the results from these tests exclusively analyse permeability evolution related to mechanical compaction and have no way of assessing the influence of chemical compaction during burial which also plays a significant role in the evolution of hyaloclastites. Three hyaloclastite samples and one welded clastogenic lava sample were tested (Figure 8). In all hyaloclastite matrix tests, the samples failed non-elastically during the experiments when pressures reached 30,50 and $70 \mathrm{MPa}$ for the VB, GHip and HBp respectively. At each of these pressures for the respective samples an audible mechanical failure of the sample was heard (cracking sound coming from the sample chamber) prior to the down pressure pathway and was associated with a significant drop in permeability from the initially measured values. In Figure 8, permeability recorded at uniform Pf (input flow pressure) and increasing confining pressures are plotted for the four experiments. Pressure is plotted increasing downwards to represent the increase in overburden with increasing burial. Based on a standard overburden pressure gradient of $1 \mathrm{psi} / \mathrm{ft}$, the weakest samples would be expected to fail from around 1-1.5 km. With the addition of rapid alteration and associated pore occlusion (e.g. Walton and Schiffman, 2003; Watton et al., 2014) these facies would most likely form sealing units rather than reservoirs at depths of c. 1.5-2 
$\mathrm{km}$ or deeper, although the local influence of thermal gradient and overburden lithology may influence this transition significantly.

The comparative plots for the separate hyaloclastite facies all display a relatively similar story of rapidly reducing permeability with increasing confining pressure followed by (at the experimental sample scale) brittle failure

and further permeability reduction, albeit at slightly different pressures for different facies. In the case of the clastogenic lava (note that the Pf is increased to $0.6 \mathrm{MPa}$ here due to its much lower starting permeability and so the permeabilities are not directly comparable to the hyaloclastite values measured at Pf $0.2 \mathrm{MPa}$ ), the permeability of this facies at the surface may be almost entirely maintained up to burial depths of c. $4 \mathrm{~km}$ if only the mechanical forces of progressing overburden are considered (e.g. Millett et al., 2016). Clearly chemical alteration may have an important influence on permeability evolution beyond simple mechanical compaction (e.g. Jerram et al., 2019), however, it is an important point that different volcanic facies in close proximity to each other may have significantly different mechanical strengths which contribute to highly variable fluid flow evolution and preservation potential during early burial.

\section{Discussion}

The detailed classification of the Hjörleifshöfði sequence into separate facies units has enabled targeted sampling to assess the petrophysical variations found within this complex hyaloclastite delta system. The young age, shallow burial and relatively fresh nature of the sequence also means that the measured properties represent perhaps some of the best examples for primary properties of a lithified hyaloclastite sequence. This is important, because the properties of the sampled sequence give fundamental insights into early fluid flow potential within this setting which in turn may have a strong influence on how alteration and secondary mineralization evolve and change these pathways during burial.

\subsection{Petrophysical properties of hyaloclastites}

The porosity values in the Hjörleifshöfði samples represent the petrophysical properties of near-primary hyaloclastite facies. Porosity of basaltic hyaloclastite in the subsurface is heavily influenced by the precipitation of interstitial secondary minerals formed by circulation of hydrothermal fluids during burial (Franzson et al., 2010), the extent of which depends on the hyaloclastite composition, permeability, temperature and fluid composition (Thien et al., 2015). Diagenesis and alteration of hyaloclastite begins at the time of eruption with palagonitisation of sideromelane glass (Franzson et al., 2010). Alteration begins quickly after burial due to the general instability of basaltic glass with continued exposure to aquatic/geothermal fluids. Palagonite is the first stable product of volcanic glass alteration (Stroncik and Schmincke 2002), and within hyaloclastite sequences the abundant basaltic glass initially devitrifies into palagonite before altering to smectite and zeolite during later stages of diagenesis. This is somewhat different to the earlier sequence of alteration common in subaerial lavas (e.g. Neuhoff et al., 1999) due to the extensive glass, but then follows a similar Clay and Zeolite pattern of burial diagenesis in basaltic material.

In volcanically active areas, igneous intrusions also provide localised or regionally elevated heat profiles (e.g. Planke et al., 2005; Iyer et al., 2017; Reynolds et al., 2017). The intrusion observed at Hjörleifshöfdi is relatively small, however, volcanically active areas commonly contain extensive intrusive suites (e.g. Thomson 2005; Planke et 
al., 2005; Thomson \& Schofield, 2012; Schofield et al., 2017), and in 3D, additional intrusions may have affected the alteration of the Hjörleifshöfdi sequence. In low grade metamorphic conditions, the transformation of zeolites and smectite to less hydrous chlorite and epidote minerals drives devolatilization reactions and may further complicate reservoir prediction models.

Within the analysed samples, variations in alteration are observed to have affected some units more than others e.g. HBp, initially indicating that there is a facies control on the rate and development of alteration. Additional sampling would be required to quantify the effects of alteration on different facies, however, from our samples, it appears that the better the sorting, the lower the influence of incipient alteration on the permeability of the samples.

In Figure 8, data from a Paleocene aged hyaloclastite sequence on the Isle of Skye, Scotland, are presented to give insights into the effects of age and increased burial (Angkasa et al., 2017). The Skye data form a coherent trend of very low porosity and permeability, demonstrating the clear age dependence of the samples and highlighting the properties that the Iceland samples would likely move towards with time and burial. Assessing the precise mechanisms and order of changes is challenging, however, from the confining pressure experiments it is clear that mechanical compaction/failure will play an important role in property changes during burial for the hyaloclastite facies. This along with the high reactivity of the glassy components suggests that these and similar hyaloclastite facies will likely move towards sealing rather than reservoir properties somewhere around $1.5-2 \mathrm{~km}$ burial.

Velocity and density profiles vary according to variations in matrix components, porosity and the composition of any pore-filling minerals (Planke, 1994). Since sonic velocity is influenced by the rigidity of the rock matrix, micro-cracks in grain boundaries act to lower the overall velocity. The data from Skye form a cluster with porosities $<10 \%$ and seismic velocities range between c. $1.5-3 \mathrm{~km} / \mathrm{s}$. Despite the marked porosity decrease in the older hyaloclastites, $\mathrm{Vp}$ remains within the same velocity ranges as the younger Icelandic deposits, suggesting that interconnected clay networks within the rocks are reducing the velocity (e.g. Planke, 1994).

\subsection{Property distribution models}

Poor core recovery in the lab due to the weak nature of the facies significantly restricted the data available for each lithofacies, and as a result, statistically robust property averages could not be produced. However, with the data that is available, we have opted to compile visual property distribution models incorporating the available petrophysical data (Table 2), the extensive lithofacies information available from the 3D model and field work, along with inferences from the published literature. In Figure 9, a profile through the 3D model is presented (flattened to a 2D plane) along with the interpreted variations in P-wave velocity. A simplified average velocity model is also presented in order to display the broad zonation of the sequence at something more approaching seismic resolution.

It is clear from Figure 9 that the dominant variations in velocity within the sequence are horizontally layered similar to clastic sedimentary sequences. The major variations in velocity beyond the background measured matrix averages are further inferred to relate to grain size and sorting, with intervals displaying increased proportions of large clasts, pillows and coarse blocky breccia horizons inferred to result in increases in velocity. Other key features relate to the structural and deformation influences on the sequence such as the major slumping that has affected the NW portion of the profile which is represented by a bending of the strata bed forms. Although this feature is clear in the image, the expected impedance contrasts between these layers internal to facies GHip are not expected to be large and 
therefore, how visible this deformation would be within seismic data is debatable. Faulting in the sequence has been represented as zones of dampened low average velocity overprinting the background values.

An important point relating to the studied sequence is the likely visibility of the detailed features at a range of scales in a hypothetical seismic survey scenario. Assuming reasonable values of velocity (3000 m/s) and wavelength $(40 \mathrm{~Hz})$ for a shallow seismic survey and a vertical resolution of $1 / 4$ the dominant wavelet gives a maximum vertical resolution of c. $18 \mathrm{~m}$. Applying this order of resolution to the model suggests that many, but not all of the individual bed forms would be below seismic resolution and would in turn reveal interference phenomena rather than specific layers. In both cases, the identified $\mathrm{Vp}$ (coupled with density) variability should reveal significant resolvable variations in seismic data, enabling at least the general architecture of the sequence to be resolved. Given the significant changes in petrophysical properties for older hyaloclastite sequences (Angkasa et al., 2017), and the tendency for properties such as Vp and density to converge into tight arrays (e.g. Nelson et al., 2009), the critical question for subsurface imaging is how long the variations identified in this study will remain clearly visible. One example of a subsurface offshore seismic line through a Palaeogene mixed hyaloclastite/reworked volcaniclastic sequence is presented in Millett et al. (2015). In this case, the seismic response becomes almost transparent in places, whilst in other areas foresets are visible, highlighting the effect of burial and alteration on potentially reducing the initial petrophysical variability and therefore imaging potential of these types of sequences.

In Figure 10, the same profile has been coloured according to porosity data provided in Table 2. This model intends to apply properties measured from core plugs of representative members from each facies to establish a simple model for porosity architecture at the facies scale. Again, a simplified version based on the average porosity measured from the core plugs has been provided. Similar to the velocity model it is clear that the dominant variations in porosity are bedding constrained and relate mostly to inferred sorting. The abundance of fine grained interstitial grains that fill pores are most susceptible to alteration due to the larger surface areas of constituent grains. A key observation from this study is that all of the hyaloclastite matrix samples reveal significant flow potential, and therefore, even though significant variations exist, it appears reasonable to infer that the entire sequence can be regarded as 'open' to fluid flow consistent with the hypothesis of Thien et al. (2015). The highest likelihood for major impediments to fluid flow in these systems therefore appear to be either faults (if sealing), or facies such as dikes or lava flow interiors. No evidence of fault sealing has been observed in the section, however, both dikes and subaerial lavas are present within the area and are known to form effective seals in other scenarios (e.g. Millett et al., 2016; Grove et al. 2017). For the hyaloclastite facies, it therefore appears inevitable from the current evidence, that these facies will become altered and the pore throats will become restricted by secondary minerals during burial diagenesis consistent with studies of older previously or currently buried sequences (Walton and Schiffman, 2003; Nelson et al., 2009; Millett et al., 2015).

\subsection{Pseudo-well logs}

Hyaloclastite sequences have been investigated from borehole data (wireline, core, cuttings) in many studies globally and reveal a range of typical log signatures depending on age and setting (Watton et al., 2014; Nelson et al., 2009; Millett et al., 2015). Given that boreholes provide the only means of accessing both lithology and highresolution geophysical data for hyaloclastite sequences, bridging the gap between borehole data and field analogue 
studies is highly important. To supplement the property distribution maps outlined above, we have also compiled simplified log profiles through the 3D model in order to highlight the likely 1D property variability that may be expected from borehole penetrations using a similar approach to Angkasa et al. (2017). Two pseudo-log positions were chosen to demonstrate the lateral heterogeneity of the system (Figure 9).

The pseudo-logs showing inferred velocity and density are shown in Figure 11 and have been compiled based on the petrophysical data from this study along with the lithological logs provided by Watton et al. (2013). Average values from Table 2 were compared with clast percent information to estimate velocity and density profiles according to matrix-clast proportions. The extent of zeolite formation is broadly proportional to the clast percentage (Watton et al., 2013). The estimated seismic velocity is inferred to fluctuate between $2.5-5.2 \mathrm{~km} / \mathrm{s}$ in the section and density profiles range between 1.8 and $3 \mathrm{~g} / \mathrm{cm}^{3}$ for the full sequence. Figure $11 \mathrm{~b}$ shows the $\log$ profile for the hyaloclastite slump where contrasts in bed morphology (i.e. grading reversals) and clast-rich intervals cause a wider variation in seismic velocity $(\sim 2.3-3.5 \mathrm{~km} / \mathrm{s})$ and density $\left(\sim 1.5-2.7 \mathrm{~g} / \mathrm{cm}^{3}\right)$.

In order to compare the pseudo-logs to real examples, velocity profiles for two other hyaloclastite sequences drilled at depth in Hawaii (Watton et al., 2014) and the Faroe Islands (Nelson et al., 2009) are shown in Figure 11a. Velocity at $\sim 1.8 \mathrm{~km}$ depth averages between $4.7-5.1 \mathrm{~km} / \mathrm{s}$ and $4.8-5.2 \mathrm{~km} / \mathrm{s}$ at $\sim 2.8 \mathrm{~km}$ depth in Hawaii. Both subsurface datasets show reasonably smooth $\mathrm{Vp}$ velocities compared to the velocity and density pseudo-logs for Hjörleifshöfði, where average velocities fluctuate between 1.5 and $5.2 \mathrm{~km} / \mathrm{s}$. This difference reflects the previously discussed variations related to the age and lack of burial of the studied sequence in this study. Another important point in terms of the absolute values, is the fact that the borehole studies are measuring saturated properties, whilst in this study all data measurements were made on dry samples. This forms an important difference which can be somewhat accounted for by fluid substitution analyses, however, this does not significantly reduce the additional scatter of the recent compared to older samples. The pseudo-logs again highlight the clear differences between young, relatively fresh hyaloclastite which show highly variable facies related properties, compared to older buried sequences that often display highly uniform properties.

\subsection{Identifying base-level changes}

The fundamental difference in the physical responses for hyaloclastites of different ages has a number of important implications for subsurface interpretation. One key implication of this study is that, for older subsurface sequences, significant variations in the hyaloclastite facies type along with major bounding surfaces between different facies units may be very hard to delineate after burial and pervasive alteration. The implication of this is that major changes in base-level during hyaloclastite delta development, along with major environmental and three-dimensional facies changes that could give important information relating to basin evolution, may be easily missed. The stratigraphic sequence at Hjörleifshöfði is punctuated by at least three periods of non-deposition and erosion that facilitated the dispersion of the reworked material further downslope. The erosional unconformities between the HBp, GHip and VStcb facies, each indicate shallowing of the system and a change in depositional environment. We currently have no constraints on the time-frame for these erosional events, however, due to the vulnerable and weak nature of the facies (e.g. Schiffman et al., 2006), they could potentially have occurred very rapidly. Destabilisation of 
delta margins takes place by wave erosion and undercutting of the hyaloclastite terraces, leading to collapse and synsedimentary hyaloclastite deposition (e.g. Mattox \& Mangan, 1997; Smellie \& Hole, 1997).

Each change in environment across these erosional boundaries could represent either a period of relative uplift, liquefaction, earthquake remobilization or simply the slope building above a stable angle of repose (Mattox \& Mangan 1997; Ollier et al., 1998; Head \& Wilson, 2003; Sohn et al., 2008). In the dynamic geological setting of southern Iceland, causes of uplift and subsidence could have a number of origins ranging from eustatic sea level changes (Miller et al., 2011), glacial loading and rebound (Einarsson and Albertson, 1988; Sigmundsson, 1991), regionally influenced dynamic topography (Parnell-Turner et al., 2014), or local magma chamber inflation and deflation (Sturkell et al., 2006; Galland, 2012). Given the young age of the deposits and the clear evidence for local eruptions during the build-up of the sequence, we currently prefer a local cause of relative base level changes associated with periodic recharge/inflation and eruption/subsidence of a local magma chamber (e.g. O'Hara and Mathews, 1981) that fed the evolving Surtseyan edifice. Additionally, local reworking, slope instability and the influence of local to regional seismic activity may also have contributed to incision during the edifice build-up as noted above.

\section{Conclusions}

Within this study we have presented an integrated field, photogrammetry and petrophysical based interpretation of a complex hyaloclastite sequence. The ability to image in 3D and predict the geophysical architecture of these systems is important to help understand their formation and to better quantify how these sequences change at variable depths of burial and age, which ultimately result in their present day rock properties in the subsurface.

The lithofacies characteristics in our study are attributed to a shallow slope marine depositional sequence showing a shallowing upward profile, interpreted as evidence of a prograding and emergent delta forming as part of a Surtseyan volcano. Detailed photogrammetry and the production of a 3D outcrop model enabled quantitative outcrop analysis and the identification of major erosional unconformities within the modelled sequence evolution.

Porosity and permeability data show significant variations between facies, however, all hyaloclastite matrix facies demonstrate relatively high fluid flow potential suggesting that hyaloclastite sequences will dominantly act as open systems for fluid flow at shallow burial prior to pervasive alteration/cementation with increasing temperature and pressure, as demonstrated by offshore examples. The generation of property distribution models for Vp and porosity along with pseudo-wireline log signatures has revealed insights into the possible effects that pervasive reworking and slumping processes have had on the 3D distribution of petrophysical variations. These models allow inference as to the likely lateral variability of properties in this and similar subsurface systems. Confining pressure permeability experiments have confirmed that relatively young hyaloclastite matrix facies are mechanically weak and will undergo significant failure and permeability decreases above c. $30 \mathrm{MPa}$ confining pressure.

Finally, our results highlight that the petrophysical properties of young hyaloclastite facies can be highly variable as a function of lava composition, depositional style, alteration and pore structure. The present study is based on a 3D model developed over an outcrop transect which covers a range of $>1 \mathrm{~km}$ wide by $>200 \mathrm{~m}$ high. The transect was chosen as it provided a well constrained outcrop example with exceptional 3D exposure of a young emergent sequence, along with clear facies types and associations (Watton et al., 2013). Further, expansion of this model would 
help to constrain the hyaloclastite architecture beyond the $1 \mathrm{~km}$ scale laterally, where additional outcrop allows, realising any further boundaries and associations not fully realised in the current model. Older sequences of varying thickness, in contrast, commonly show more uniform rock properties resulting from a combination of pervasive alteration, secondary mineralization and burial compaction (e.g. Nelson et al., 2009; Angkasa et al., 2017). This has the effect of reducing the potential for identifying sequence boundaries, facies variations and base-level changes in older buried sequences from remote data.

\section{Acknowledgements}

Dougal Jerram is partly funded through a Norwegian Research Council Centres of Excellence project (project number 223272, CEED). Adam Soule, Kirstie Wright and an anonymous reviewer are thanked for their extensive comments which helped to improve the final manuscript. We thank Cynthia Ebinger for clear editorial guidance and handing of the manuscript.

\section{Data Availability Statement}

The data that support the findings of this study are provided in the supplementary material.

\section{References}

Abdelmalak, M.M., S. Planke, J.I. Faleide, D.A. Jerram, D. Zastrozhnov, S. Eide, R. Myklebust, 2016. The development of volcanic sequences at rifted margins: new insights from the structure and morphology of the Vøring Escarpment, mid-Norwegian Margin J. Geophys. Res. Solid Earth, 121, 5212-5236

Alsop, G. I. \& Marco, S. 2013. Seismogenic slump folds formed by gravity-driven tectonics down a negligible subaqueous slope. Tectonophysics, 605, 48-69.

Angkasa, S., Jerram, D.A., Millett, J.M., Svensen, H.H., Planke, S., Taylor, R.A., Schofield, N., Howell, J., 2017. Mafic intrusions, hydrothermal venting, and the basalt-sediment transition: Linking onshore and offshore examples from the North Atlantic igneous province. Interpretation 5 (3), SK83-SK101.

Bartetzko, A., Delius, H. and Pechnig, R., 2005. Effect of compositional and structural variations on log responses of igneous and metamorphic rocks. I: mafic rocks. Geological Society, London, Special Publications, 240(1), 255-278.

Buckley, S.J., Howell, J.A., Enge, H.D. and Kurz, T.H., 2008. Terrestrial laser scanning in geology: data acquisition, processing and accuracy considerations. Journal of the Geological Society, 165(3), pp.625-638.

Eide, C.H., Schofield, N., Jerram, D.A. and Howell, J.A., 2017. Basin-scale architecture of deeply emplaced sill complexes: Jameson Land, East Greenland. Journal of the Geological Society, 174(1), pp.23-40.

Einarsson, T. and Albertsson, K.J., 1988. The glacial history of Iceland during the past three million years. Phil. Trans. R. Soc. Lond. B, 318(1191), pp.637-644.

Enge, H.D. and Howell, J.A., 2010. Impact of deltaic clinothems on reservoir performance: Dynamic studies of reservoir analogs from the Ferron Sandstone Member and Panther Tongue, Utah. AAPG bulletin, 94(2), pp.139-161. 
Farrell, N.J.C., Healy, D. and Taylor, C.W., 2014. Anisotropy of permeability in faulted porous sandstones. Journal of Structural Geology, 63, pp.50-67.

Fitzgerald, E. M. and Bean, C. J. 2001. Sub-basalt imaging problems and the application of Artificial Neural Networks. Journal of Applied Geophysics, 48, 183-197.

Franzson, H., Guofinnsson, G. H., et al. 2010. Porosity, density and chemical composition relationships in altered Icelandic hyaloclastites. Water-Rock Interaction - Proceedings of the 13th International Conference on WaterRock Interaction, WRI-13., 199-202.

Frolova, J., Ladygin, V., Franzson, H., Sigurdsson, o., Stefansson, V. \& Sustrov, V. 2005. Petrophysical properties of fresh to mildly altered hyaloclastite tuffs. Proc. World Geothermal Congress, Antalya, Turkey: 15p.

Fuller, R.E., 1931. The aqueous chilling of basaltic lava on the Columbia River Plateau. American Journal of Science 21, 281-300.

Furnes, H. \& Fridleifsson, I. B. 1974. Tidal effects on the formation of pillow lava/hyaloclastite deltas. Geology, 2, 381-384.

Furnes, H., Hellevang, H., et al. 2003. Volcanic evolution of oceanic crust in a Late Ordovician back-arc basin: The Solund-Stavfjord Ophiolite Complex, West Norway. Geochemistry, Geophysics, Geosystems, 4.

Galland, O., 2012. Experimental modelling of ground deformation associated with shallow magma intrusions. Earth and Planetary Science Letters, 317, pp.145-156.

Grove, C., Jerram, D.A., Gluyas, J.G. and Brown, R.J., 2017. Sandstone Diagenesis in Sediment-lava Sequences: Exceptional Examples of Volcanically Driven Diagenetic Compartmentalization in Dune Valley, Huab Outliers, Nw Namibia. Journal of Sedimentary Research, 87(12), pp.1314-1335.

Hanson, R. E. \& Schweickert, R. A. 1982. Chilling and brecciation of a Devonian rhyolite sill intruded into wet sediments, northern Sierra Nevada, California. Journal of Geology, 90, 717-724.

Head III, J. W. \& Wilson, L. 2003. Deep submarine pyroclastic eruptions: Theory and predicted landforms and deposits. Journal of Volcanology and Geothermal Research, 121, 155-193.

Iyer, K., Schmid, D.W., Planke, S. and Millett, J., 2017. Modelling hydrothermal venting in volcanic sedimentary basins: Impact on hydrocarbon maturation and paleoclimate. Earth and Planetary Science Letters, 467, pp.3042.

James, M. \& Varley, N. (2012). Identification of structural controls in an active lava dome with high resolution DEMs: Volcán de Colima, Mexico. Geophysical Research Letters. 39. L22303. 10.1029/2012GL054245.

Jerram D.A., Svensen, H.H., Planke, S., Polozov, A.G., \& Torsvik, T.H. (2016b). The onset of flood volcanism in the north-western part of the Siberian Traps: Explosive volcanism versus effusive lava flows. Palaeogeography, Palaeoclimatology, Palaeoecology, 441 (1), 38-50.

Jerram D.A., Widdowson, M., Wignall, P.B., Sun, Y., Lai, X., Bond, D.P.G., \& Torsvik, T.H. (2016a). Submarine palaeoenvironments during Emeishan flood basalt volcanism, SW China: Implications for plume-lithosphere interaction during the Capitanian, Middle Permian ('end Guadalupian') extinction event. Palaeogeography, Palaeoclimatology, Palaeoecology, 441 (1), 65-73.

Jerram, D. A., Single, R. T., et al. 2009. Understanding the offshore flood basalt sequence using onshore volcanic facies analogues: An example from the Faroe-Shetland basin. Geological Magazine, 146, 353-367.

This article is protected by copyright. All rights reserved 
Jerram, D.A., I.R. Sharp, T.H. Torsvik, R. Poulsen, T. Watton, U. Freitag, A. Halton, S.C. Sherlock, J.A.S. Malley, A. Finley, J. Roberge, R. Swart, C. Puigdefabregas, C.H. Ferreira, V. Machado, 2018.Volcanic constraints on the unzipping of Africa from South America: Insights from new geochronological controls along the Angola margin, Tectonophysics, https://doi.org/10.1016/j.tecto.2018.07.027.

Jerram, D. A., Millett, J. M., Kück, J., Thomas, D., Planke, S., Haskins, E., Lautze, N., and Pierdominici, S. 2019. Understanding volcanic facies in the subsurface: a combined core, wireline logging and image log data set from the PTA2 and KMA1 boreholes, Big Island, Hawai i, Sci. Dril., 25, 15-33, https://doi.org/10.5194/sd-2515-2019.

Johnson, J. S. \& Smellie, J. L. 2007. Zeolite compositions as proxies for eruptive paleoenvironment. Geochemistry, Geophysics, Geosystems, $\mathbf{8}$.

Klinkenberg, L.J., 1941, January. The permeability of porous media to liquids and gases. In Drilling and production practice. American Petroleum Institute.

Labourdette, R. \& Jones, R. R. 2007. Characterization of fluvial architectural elements using a three-dimensional outcrop data set: Escanilla braided system, south-central pyrenees, Spain. Geosphere, 3, 422-434.

Lipman, P. W. \& Moore, J. G. 1996. Mauna Loa lava accumulation rates at the Hilo drill site: Formation of lava deltas during a period of declining overall volcanic growth. Journal of Geophysical Research B: Solid Earth, 101, 11631-11641.

Matter, J. M., Broecker, W. S., et al. 2009. Permanent Carbon Dioxide Storage into Basalt: The CarbFix Pilot Project, Iceland. Energy Procedia, 1, 3641-3646.

Mattox, T. N. \& Mangan, M. T. 1997. Littoral hydrovolcanic explosions: A case study of lava-seawater interaction at Kilauea Volcano. Journal of Volcanology and Geothermal Research, 75, 1-17.

McCaffrey, K. J. W., Jones, R. R., et al. 2005. Unlocking the spatial dimension: Digital technologies and the future of geoscience fieldwork. Journal of the Geological Society, 162, 927-938.

Miller, K.G., G.S. Mountain, J.D. Wright, and J.V. Browning. 2011. A 180-million-year record of sea level and ice volume variations from continental margin and deep-sea isotopic records. Oceanography 24(2):40-53, doi:10.5670/oceanog.2011.26.

Millett, J.M., Hole, M.J., Jolley, D.W., Schofield, N. and Campbell, E., 2015. Frontier exploration and the North Atlantic Igneous Province: new insights from a $2.6 \mathrm{~km}$ offshore volcanic sequence in the NE Faroe-Shetland Basin. Journal of the Geological Society, 173(2), 320-336.

Millett, J.M., Planke, S., Kästner, F., Blischke, A., Hersir, G.P., Halldórsdóttir, S., Flóvenz, Ó.G., Árnadóttir, S., Helgadóttir, H.M., Vakulenko, S. and Buryak, S., 2018. Sub-surface geology and velocity structure of the Krafla high temperature geothermal field, Iceland: Integrated ditch cuttings, wireline and zero offset vertical seismic profile analysis. Journal of Volcanology and Geothermal Research. https://doi.org/10.1016/j.jvolgeores.2018.03.024

Millett, J.M., Wilkins, A.D., Campbell, E., Hole, M.J., Taylor, R.A., Healy, D., Jerram, D.A., Jolley, D.W., Planke, S., Archer, S.G. and Blischke, A., 2016. The geology of offshore drilling through basalt sequences: Understanding operational complications to improve efficiency. Marine and Petroleum Geology, 77, 1177-1192.

This article is protected by copyright. All rights reserved 
Moore, J. G., Phillips, R. L., et al. 1973. Flow of lava into the sea, 1969-1971, kilauea volcano, Hawaii. Bulletin of the Geological Society of America, 84, 537-546.

Nelson, C. E., Jerram, D. A., et al. 2009. Flood basalt facies from borehole data: Implications for prospectivity and volcanology in volcanic rifted margins. Petroleum Geoscience, 15, 313-324.

Nelson, C.E., Jerram, D.A., Hobbs, R.W., Terrington, R., Kessler, H., 2011. Reconstructing flood basalt lava flows in three dimensions using terrestrial laser scanning. Geosphere 7 (1), 87-96.

Neuhoff, P. S., Fridriksson, T., et al. 1999. Porosity evolution and mineral paragenesis during low-grade metamorphism of basaltic lavas Atteigarhorn, eastern Iceland. American Journal of Science, 299, 467-501.

Neuhoff, P.S., Fridriksson, T. and Bird, D.K., 2000. Zeolite parageneses in the north Atlantic igneous province: Implications for geotectonics and groundwater quality of basaltic crust. International Geology Review, 42(1), pp.15-44.

Nur, A., Mavko, G., Dvorkin, J. and Galmudi, D., 1998. Critical porosity: A key to relating physical properties to porosity in rocks. The Leading Edge, 17(3), pp.357-362.

O’Hara, M.J. and Mathews, R.E., 1981. Geochemical evolution in an advancing, periodically replenished, periodically tapped, continuously fractionated magma chamber. Journal of the Geological Society, 138(3), pp.237-277.

Ollier, G., Cochonat, P., et al. 1998. Deep-sea volcaniclastic sedimentary systems: An example from La Fournaise volcano, Réunion Island, Indian Ocean. Sedimentology, 45, 293-330.

Parnell-Turner, R., White, N., Henstock, T., Murton, B., Maclennan, J. and Jones, S.M., 2014. A continuous 55million-year record of transient mantle plume activity beneath Iceland. Nature Geoscience, 7(12), p.914.

Pedersen, A.K., Larsen, L.M., Riisager, P. and Dueholm, K.S., 2002. Rates of volcanic deposition, facies changes and movements in a dynamic basin: the Nuussuaq Basin, West Greenland, around the C27n-C26r transition. Geological Society, London, Special Publications, 197(1), pp.157-181.

Petersen, U.K., Brown, R. and Andersen, M.S., 2013. P-wave velocity distribution in basalt flows of the Enni Formation in the Faroe Islands from refraction seismic analysis. Geophysical Prospecting, 61(1), pp.168-186.

Planke, S., 1994. Geophysical response of flood basalts from analysis of wire line logs: Ocean Drilling Program Site 642, Vøring volcanic margin. Journal of Geophysical Research: Solid Earth, 99(B5), pp.9279-9296.

Planke, S., and Cambray, H., 1998, Seismic properties of flood basalts from Hole 917A downhole data, southeast Greenland volcanic margin, Proc. Ocean Drill. Program Sci. Results, 152, 453 - 464.

Planke, S., Millett, J.M., Maharjan, D., Jerram, D.A., Abdelmalak, M.M., Groth, A., Hoffmann, J., Berdnt, C. and Myklebust, R., 2017. Igneous seismic geomorphology of buried lava fields and coastal escarpments on the Vøring volcanic rifted margin. Interpretation, 5(3), 1-42.

Planke, S., Rasmussen, T., et al. 2005. Seismic characteristics and distribution of volcanic intrusions and hydrothermal vent complexes in the Vøring and Møre basins. Petroleum Geology Conference Proceedings, 6 , 833-844.

Planke, S., Symonds, P., Alvestad, E., and Skogseid, J., 2000. Seismic volcanostratigraphy of large-volume basaltic extrusive complexes on rifted margins. J. of Geophys. Res., 105, 19335-19351.

This article is protected by copyright. All rights reserved 
Reynolds, P., Planke, S., Millett, J.M., Jerram, D.A., Trulsvik, M., Schofield, N. and Myklebust, R., 2017. Hydrothermal vent complexes offshore Northeast Greenland: A potential role in driving the PETM. Earth and Planetary Science Letters, 467, 72-78.

Sætre, C., Hellevang, H., Dennehy, C., Dypvik, H. \& Clark, S., 2018. A diagenetic study of intrabasaltic siliciclastics sandstones from the Rosebank field. Marine and Petroleum Geology, 98, 335-355.

Santilano, A., Manzella, G., Gianelli, G., Donato, A., Gola, G., Nardini, I., Trumpy, E., and Botteghi, S., 2015. Convective, intrusive geothermal plays: what about tectonics? Geothermal Energy Science, 3, 51-59.

Schiffman, P., Watters, R.J., Thompson, N., Walton, A.W., 2006. Hyaloclastites and the slope stability of Hawaiian volcanoes: insights from the Hawaiian scientific drilling Project's 3-km drill core. J. Volcanol. Geotherm. Res. 151, 217e228. http://dx.doi.org/10.1016/j.jvolgeores.2005.07.030.

Schofield, N. J., Brown, D. J., et al. 2012. Sill morphology and comparison of brittle and non-brittle emplacement mechanisms. Journal of the Geological Society, 169, 127-141.

Schofield, N., Holford, S., Millett, J., Brown, D., Jolley, D., Passey, S.R., Muirhead, D., Grove, C., Magee, C., Murray, J. and Hole, M., 2017. Regional magma plumbing and emplacement mechanisms of the Faroe-Shetland Sill Complex: implications for magma transport and petroleum systems within sedimentary basins. Basin Research, 29(1), pp.41-63.

Sigmundsson, F., 1991. Post-glacial rebound and asthenosphere viscosity in Iceland. Geophysical Research Letters, 18(6), pp.1131-1134.

Skilling, I. P. 2002. Basaltic pahoehoe lava-fed deltas: Large-scale characteristics, clast generation, emplacement processes and environmental discrimination. Geological Society Special Publication, 202, 91-113.

Smellie, J. L. \& Hole, M. J. 1997. Products and processes in pliocene-recent, subaqueous to emergent volcanism in the Antarctic Peninsula: Examples of englacial Surtseyan volcano construction. Bulletin of Volcanology, 58, 628-646.

Sohn, Y. K., Park, K. H., et al. 2008. Primary versus secondary and subaerial versus submarine hydrovolcanic deposits in the subsurface of Jeju Island, Korea. Sedimentology, 55, 899-924.

Stevenson, J. A., Mitchell, N. C., et al. 2012. Lava penetrating water: The different behaviours of pahoehoe and 'a'a at the Nesjahraun, Thingvellir, Iceland. Bulletin of Volcanology, 74, 33-46.

Stroncik, N.A. and Schmincke, H.U., 2002. Palagonite-a review. International Journal of Earth Sciences, 91(4), pp.680-697.

Sturkell, E., Einarsson, P., Sigmundsson, F., Geirsson, H., Olafsson, H., Pedersen, R., de Zeeuw-van Dalfsen, E., Linde, A.T., Sacks, S.I. and Stefánsson, R., 2006. Volcano geodesy and magma dynamics in Iceland. Journal of Volcanology and Geothermal Research, 150(1-3), pp.14-34.

Sun, H. \& Zhong, D., 2018. Origin and forming process of the porosity in volcanic hydrocarbon reservoirs of China. Journal of Volcanology and Geothermal Research, 350, 61-68.

Thien, B.M., Kosakowski, G. and Kulik, D.A., 2015. Differential alteration of basaltic lava flows and hyaloclastites in Icelandic hydrothermal systems. Geothermal Energy, 3(1), p.11.

Thomson, K. \& Schofield, N. 2008. Lithological and structural controls on the emplacement and morphology of sills in sedimentary basins. Geological Society Special Publication, 302, 31-44. 
Thomson, K. 2005. Volcanic features of the North Rockall Trough: Application of visualisation techniques on 3D seismic reflection data. Bulletin of Volcanology, 67, 116-128.

Tribble, G. W. 1991. Underwater observations of active lava flows from Kilauea volcano, Hawaii. Geology, 19, 633636.

Tuffen, H. 2007. Models of ice melting and edifice growth at the onset of subglacial basaltic eruptions. Journal of Geophysical Research: Solid Earth, 112.

Vollgger, S. A. \& Cruden, A. R. 2016. Mapping folds and fractures in basement and cover rocks using UAV photogrammetry, Cape Liptrap and Cape Paterson, Victoria, Australia. Journal of Structural Geology, 85, 168187.

Vosgerau, H., Passey, S.R., Svennevig, K., Strunck, M.N. \& Jolley, D.W., 2016. Reservoir architectures of interlava systems: a 3D photogrammetrical study of Eocene cliff sections, Faroe Islands. From: Bowman, M., Smyth, H. R., Good, T. R., Passey, S. R., Hirst, J. P. P. \& Jordan, C. J. (eds). The Value of Outcrop Studies in Reducing Subsurface Uncertainty and Risk in Hydrocarbon Exploration and Production. Geological Society, London, Special Publications, 436, 55-73

Walker, G. P. L. \& Croasdale, R. 1971. Characteristics of some basaltic pyroclastics. Bulletin Volcanologique, 35, 303-317.

Walton, A.W. and Schiffman, P., 2003. Alteration of hyaloclastites in the HSDP 2 Phase 1 Drill Core 1. Description and paragenesis. Geochemistry, Geophysics, Geosystems, 4(5).

Watton, T. J., Jerram, D. A., et al. 2013. Three-dimensional lithofacies variations in hyaloclastite deposits. Journal of Volcanology and Geothermal Research, 250, 19-33.

Watton, T. J., Wright, K. A., et al. 2014. The petrophysical and petrographical properties of hyaloclastite deposits: Implications for petroleum exploration. AAPG Bulletin, 98, 449-463.

White, J. 2000. Subaqueous eruption-fed density currents and their deposits. Precambrian Research, 101, 87-109.

Wright, K. A., Davies, R. J., et al. 2012. Application of seismic and sequence stratigraphic concepts to a lava-fed delta system in the Faroe-Shetland Basin, UK and Faroes. Basin Research, 24, 91-106.

This article is protected by copyright. All rights reserved 


\section{Figure Captions}

Table 1. Lithofacies description and interpretation in stratigraphic order, modified after Watton et al. (2013).

Table 2. Average values for lab-based petrophysical properties for the key facies present in the 3D model. All data, along with additional analyses, are presented in the online supplementary data.

Figure 1. a) Hjörleifshöfði located East of Vik, southern Iceland shown in the regional tectonic context. b) Map of volcanic facies at Hjörleifshöfði, modified after Watton et al. (2013). In this paper, we focus on the deposits associated with the subaqueous phase of eruption. Heavy black indicates the location of the modelled cliff section in the distal slope part of the lava-fed delta, the focus of this study. b) Facies map and cross section of Hjörleifshöfoi delta modified after figure $6 \mathrm{~b}$ of Watton et al. (2013). The four phases and associated lithofacies defined by Watton are shown alongside the key, simplified into the main stages discussed in our study; subaqueous build-up, emergence and reworking, to subaerial effusion. The modelled section presented in this study includes deposits from the subaqueous to emergent phase of eruption (Watton's phase 1 and 2).

Figure 2. a) Completed 3D digital reconstruction of the transect in the Agisoft software. b) Lithofacies interpretation of the modelled section highlighting the location of key relationships shown in Boxes $C-G$. The $x$ label is the estimated displacement of normal faults. Box C) Unconformity between facies HBp and GHip. Note the truncation of planar debris flows in lithofacies HBp and the subsequent onlap of the hyaloclastite breccia at an inclined angle. Box D) Reworked hyaloclastite (facies code VStcb, Watton et al. 2013) deposited onto the erosional surface of GHip. Most of the VStcb facies is out of the extent of our digital reconstruction, but the lower contact can be seen in a few places, always onlapping the eroded surface of GHip Box E) High angle normal faults completely bisect lower VB and HBP facies and partially bisects facies GHip. Erosion of GHip and deposition of VStcb occurred following the cessation of fault movement, as the VStcb facies drape the sequence. Box F) Facies HBp drape the hanging wall of the listric faults on the eastern side of Hjörleifshöfði, suggesting deposition was synchronous with edifice collapse. Box G) GHip ductile-deformed slump located in western part of the section, an indication of the wide-scale deformation and collapse of the delta flanks. Note - the profile (a) and inset boxes $C$ - $G$ are screen shots from the $3 D$ model.

Figure 3. Detailed facies interpretations. a) Detail of small saucer shaped intrusion shown with a sharp upper contact indicates initial emplacement by brittle deformation, b) Followed by further ductile type intrusion into semiconsolidated deposits. Note the broadly flat-ramp-flat morphology described by Thomson \& Schofield (2008). c) Illustration showing more detail of parasitic folding in the flank slump of facies GHip shown in Figure 2. Note the zfold geometry of the highlighted deformational area, indicating a clockwise extensional rotation direction. d) Synsedimentary faulting of facies HBp. Lapilli breccia beds clearly show infill on the hanging wall. Footwall sedimentary structures partially homogenised. e) Truncation of HBp beds and subsequent onlap of GHip. Occurrence of random large boulders indicates occasional high-density flows downslope, triggered by collapse of parts of the edifice. Notethe images presented in a-e are screen shots from the $3 D$ model. 
Figure 4. Bedding dips cross-plotted against height in model section. Both HBp facies and GHip show a shallowingup dip direction trend, interpreted as a filling up of accommodation and initial depositional architecture being controlled by the topography of eroded underlying surface.

Figure 5. Additional sampled facies from the western and northern Hjörleifshöfði peninsula. a) Pillow breccia complex (facies code iP; Watton et al., 2013) comprising sub-spherical glassy spalled pillows supported by an altered hyaloclastite matrix - armoured bombs with fragmental cores are also present. b) Tephra and quenched lapilli (facies code FA; Watton et al., 2013). Weakly bedded horizons displaying evidence for spalled pillows and bombs in a friable matrix of largely unwelded juvenile volcanic clasts. c) Columnar jointed clastogenic lava displaying tightly spaced wavy columnar jointing, overprinted onto a tightly welded fabric of glassy basaltic clasts. d) Tightly welded grained glassy matrix with some larger irregular glassy bombs.

Figure 6. Idealised facies evolution model for the volcanic sequence at Hjörleifshöfði. a) Initial submarine eruption and deposition of the primary lava complex, breccia apron and distal debris flows. b) Early-emergence and increasing volcanic energy as hydro-magmatic reactions become more energetic. c) Subaerial edifice build-up, progradation and erosion/reworking. The dotted box indicates the approximate position of the Hjörleifshöfði outcrop in the model.

Figure 7. Examples of core plugs and thin sections for the three main hyaloclastite facies that outcrop along the $3 D$ model. Note - thin sections have been impregnated with a blue dye resin to highlight porosity.

Figure 8. Petrophysical crossplots of Hjörleifshöfði data labelled with symbols according to their lithofacies (see key). a) P-wave velocity versus density cross-plot comparing the samples to the modelled trendline of Bartetzko et al. (2005). Skye hyaloclastite data shows increased rock density, but generally falls within range of the younger, lower density Icelandic hyaloclastites. b) Vp versus Vs measured on dry core plugs for Iceland samples. c) Porositypermeability cross-plot of Hjörleifshöfði data, also shown are the data fields of unaltered hyaloclastites from Iceland up to 2Ma and 2-2.5Ma (Frolova et al., 2005), and data from Skye 62Ma age (Angkasa et al., 2017). d) Plot highlighting the reduction in permeability with increasing confining pressures for selected Iceland samples prior to sample failure of the young hyaloclastite samples.

Figure 9. Section diagram to illustrate 2-D seismic velocity profile across the model according to a) average petrophysical values provided in Table 2 and b) minimum and maximum velocities used from table 2 to provide more detail for each lithofacies and take into account internal bedding variations. VB deposits show the highest average seismic velocity and velocities are reasonably consistent. GHip shows the lowest average seismic velocity and is consistently in the range of $1.2-1.7 \mathrm{~km} / \mathrm{s}$. In contrast facies HBp shows the most variability, with velocities ranging from $2.5-3.7 \mathrm{~km} / \mathrm{s}$. The small saucer-shaped intrusion can be seen as a high velocity signal in the detailed P-wave velocity profile. The positions of $\log 1 \& \log 2$ are indicated, and are focused on in Figure 11. 
Figure 10. Section profile coloured according to porosity parameters provided in table 2. a) Simplified version coloured according to average values only and b) Minimum and maximum porosity values used from table 2 to provide more detail for each lithofacies and take into account internal bedding variations. GHip show the highest average porosity and show the greatest variability, with porosities between $39.4 \%-44 \%$. VB deposits show the greatest consistency with porosity values between 32.2\% - 33.9\%. However HBp also shows high variability, with porosities ranging from 19.9\% - 27.2\%. The saucer-shaped intrusion has been coloured to show very low internal porosity.

Figure 11 a) Log 1 profile (log position shown in figure 9). 1-D lithology, velocity and density pseudo-logs for Hjörleifshöfði section; simplified lithological logs (see their supplementary materials for original logs), zeolite and clast \% data after Watton et al., 2013. Dashed line indicates key horizons. Velocity log data for subsurface hyaloclastite deltas from Hawaiian Scientific Drilling Project (Watton et al., 2014) shown in green, and Faroe Islands (Nelson et al., 2009) in blue for reference. Note that they have very little velocity variation in comparison to the Hjörleifshöfði pseudo log, this is discussed further in section 6.3. b) Log 2 seismic velocity and density pseudo-log profile through facies GHip (log position indicated in figure 9). Variations in overall bed composition (density) and arrangements cause fluctuations in the seismic response of hyaloclastites at the surface.

This article is protected by copyright. All rights reserved 
Lithofacies

Name

(abrev.)
Overview

\section{Typical}

bedding

thicknes

S
Bedding Foreset

lateral angle \&

extent spacing

\section{Unit \\ Thickness}

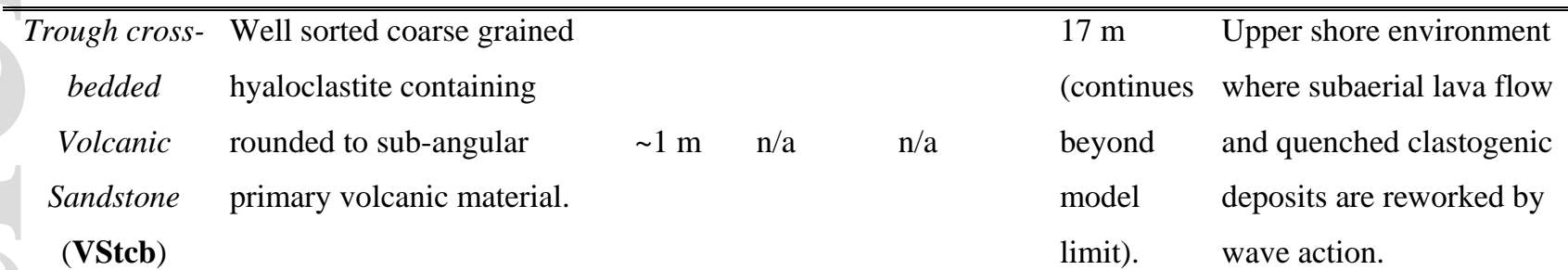

$\begin{array}{ll} & \text { Erosion/non-deposition. } \\ & \text { Local uplift by magma } \\ & \text { upwelling and/or wave } \\ & \text { erosion }\end{array}$

Erosional Undulose and erosional.

Unconformity Estimated c. 20 m erosion.

erosion

Imbricate cross- Cross bedded matrix

bedded supported breccia.

Hyaloclastite Beds typically fine up,

Breccia inclined onto erosional

(GHip) unconformity.
Typically $20-25^{\circ}$, 90-100 m spacing

2-10 $\mathrm{m}$ but $>250$ below

$\mathrm{m}$ in model places resolution
$45 \mathrm{~m}$ maximum visible.

Shallowing of the system as accommodation is filled, increasing influence of waves and reworking.

Erosion/non-deposition before a change to a shallower, higher energy setting.

Unconformity

Truncates volcanic breccia facies. GHip unit onlaps the truncated beds of HBp facies.

At least $75 \mathrm{~m}$ erosion.

Planar cross-bedded volcanic

Hyaloclastite breccia.

Breccia - Fewer large clasts than in VB.

Planar

Channels observed on eastern $1.5-4 \mathrm{~m}^{200-350}$ $\mathrm{m}$

(HBp) fallen block of listric fault; 28 -90 m wide, 6-7.5 m deep. $10^{\circ}$ spacing below model resolution
$141 \mathrm{~m}$ high on hanging Submarine volcanism and wall of eastern triggered by edifice most listric instability and reworking. fault.
Erosional Unconformity
Truncation of massive volcanic breccia beds. Low angle onlap of VbP.
Non-deposition due to hiatus or slower rate of eruption.

Poorly sorted matrix

supported breccia including

tephra, pillows and

$\sim 60 \mathrm{~m}$

Massive

vesicular/non-vesicular basalt.

$\sim 10^{\circ}$, visible on

Breccia Undulose erosional bedding $5-15 \mathrm{~m}>500 \mathrm{~m}$ spacing

(VB) contacts. $\sim 2 \mathrm{~m}$ south

Erosional channels typically facing cliffs.

High density gravity flow deposits sourced from the remobilisation of hydromagmatic material. between $30-35 \mathrm{~m}$ wide and 2$3.5 \mathrm{~m}$ deep.

Table 1. Lithofacies description and interpretation in stratigraphic order, modified after Watton et al. (2013).

This article is protected by copyright. All rights reserved 


\begin{tabular}{|c|c|c|c|c|c|c|c|c|}
\hline Facies & $\begin{array}{l}\text { \# Data } \\
\text { Points }\end{array}$ & & $\begin{array}{l}V p \\
(\mathrm{~km} / \mathrm{s})\end{array}$ & $\begin{array}{l}V s \\
(\mathrm{~km} / \mathrm{s})\end{array}$ & $\begin{array}{l}\text { Porosity } \\
\%\end{array}$ & $\begin{array}{l}\text { Permeability } \\
(m D)\end{array}$ & $\begin{array}{l}\text { Rock } \\
\text { Density } \\
\left(\mathrm{g} / \mathrm{cm}^{3}\right)\end{array}$ & $\begin{array}{l}\text { Grain } \\
\text { Density } \\
\left(\mathrm{g} / \mathrm{cm}^{3}\right)\end{array}$ \\
\hline \multirow[t]{3}{*}{$\overline{\text { GHip }}$} & $\mathrm{n}=7$ & Min & 1.23 & 0.68 & 39.45 & "595.8 & 1.14 & 2.22 \\
\hline & & $\operatorname{Max}$ & 1.72 & 1.05 & 48.69 & 4487.3 & 1.46 & 2.57 \\
\hline & & Mean & 1.57 & 0.91 & 44.02 & 2394.29 & 1.37 & 2.45 \\
\hline \multirow[t]{3}{*}{$\overline{\mathrm{HBp}}$} & $\mathrm{n}=8(\mathrm{n}=7$ & Min & 2.50 & 1.63 & 19.96 & 14.68 & 1.76 & 2.29 \\
\hline & for Por, RD & Max & 3.69 & 2.05 & 27.19 & 8784.3 & 2.04 & 2.60 \\
\hline & and GD) & Mean & 2.93 & 1.83 & 23.04 & 1557.53 & 1.85 & 2.40 \\
\hline \multirow[t]{3}{*}{ VB } & $\mathrm{n}=3$ & Min & 2.10 & 1.08 & 32.25 & 2445.7 & 1.61 & 2.44 \\
\hline & & Max & 2.62 & 1.33 & 33.97 & 4660.0 & 1.70 & 2.51 \\
\hline & & Mean & 2.28 & 1.24 & 32.96 & 3592.3 & 1.65 & 2.47 \\
\hline Dense clasts & $\mathrm{n}=5(\mathrm{n}=4$ & Min & 4.32 & 2.64 & 3.14 & 0.0017 & 2.61 & 3.05 \\
\hline (block/ bomb) & for perm.) & Max & 6.39 & 3.08 & 14.74 & 28.31 & 3.01 & 3.15 \\
\hline
\end{tabular}




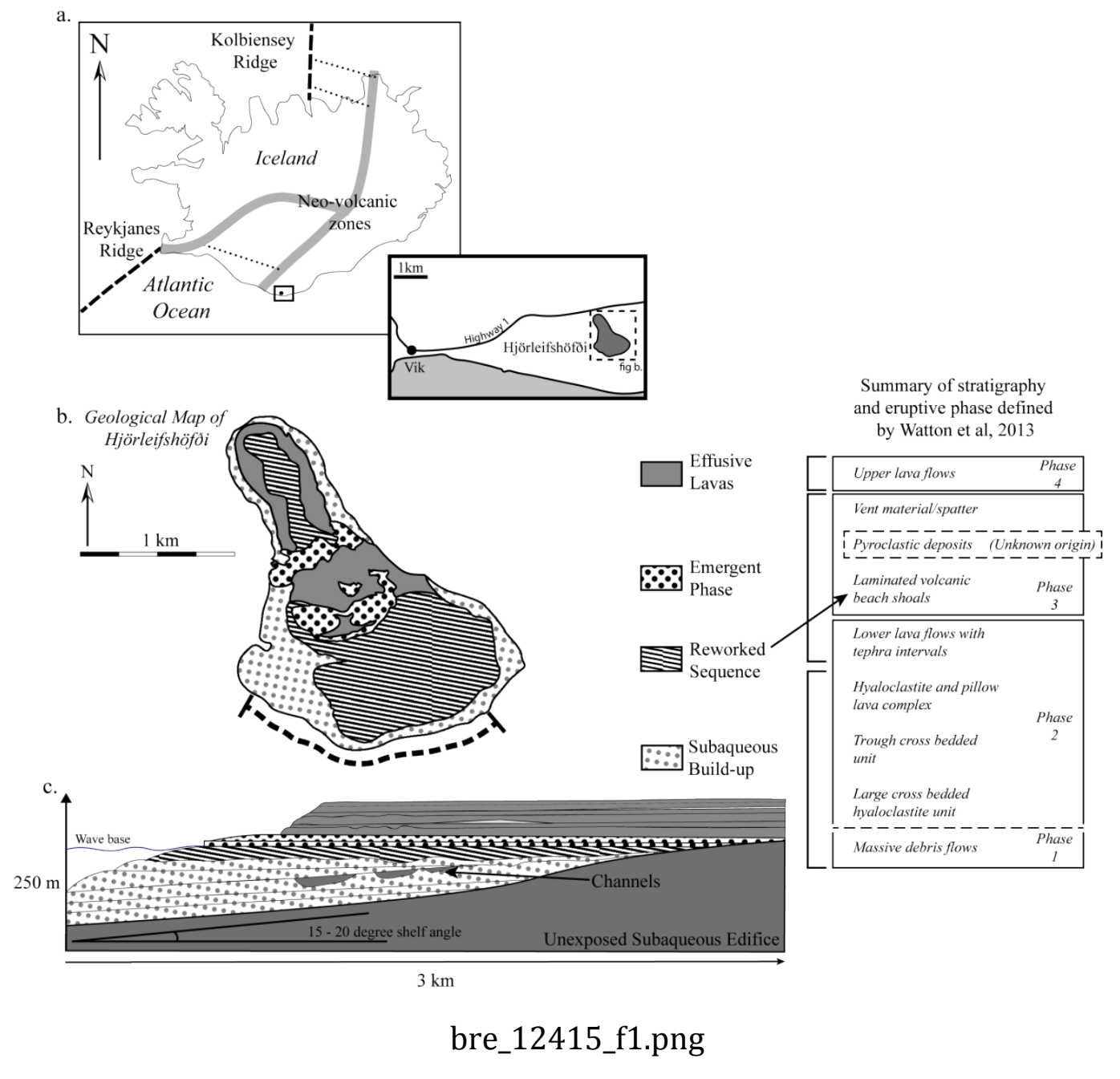

This article is protected by copyright. All rights reserved 


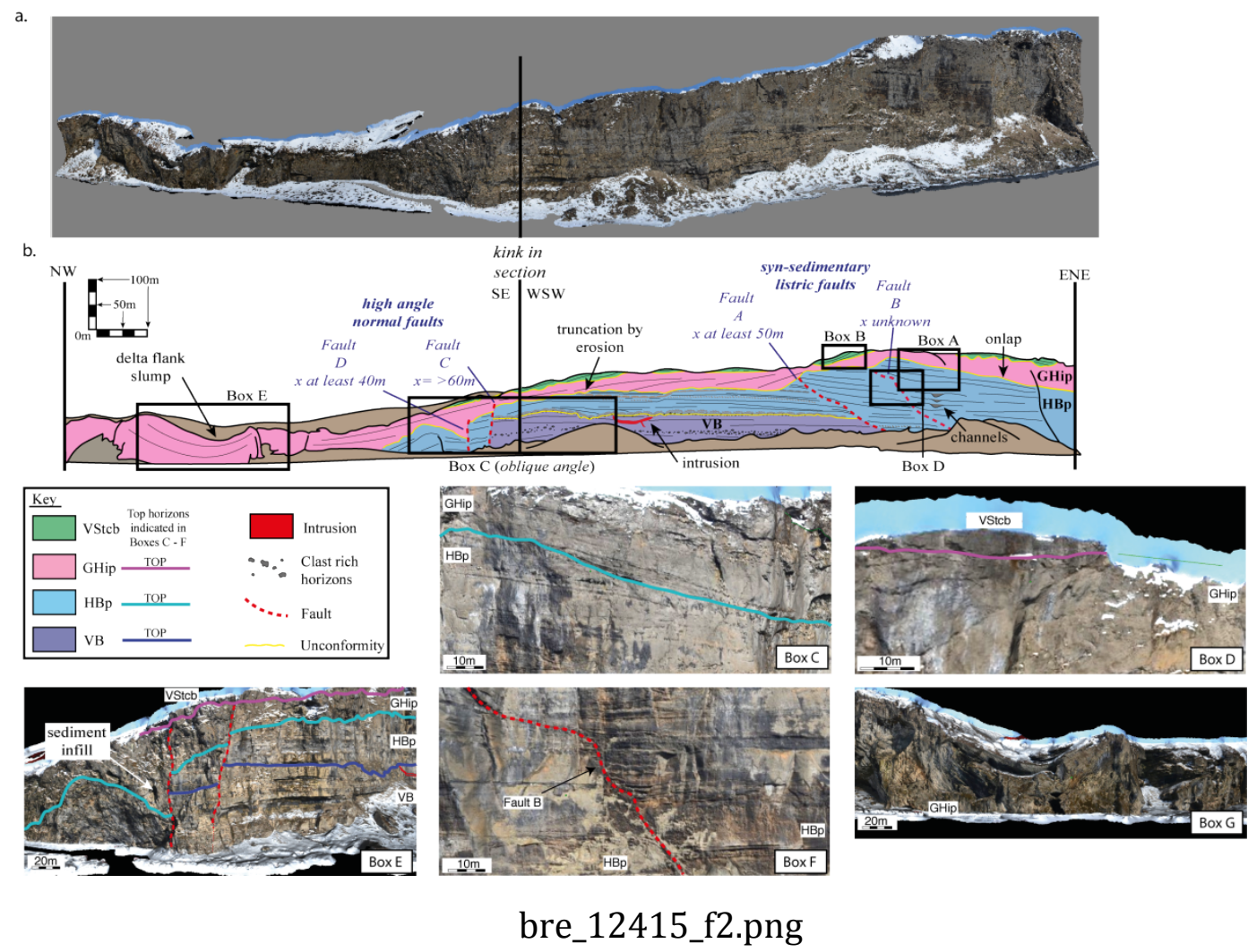

This article is protected by copyright. All rights reserved 
b.

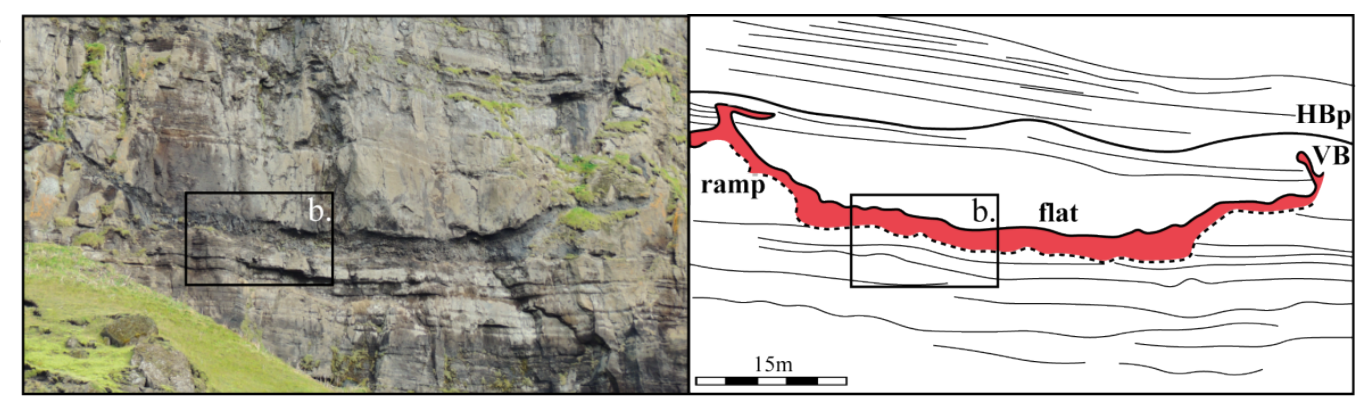

c.

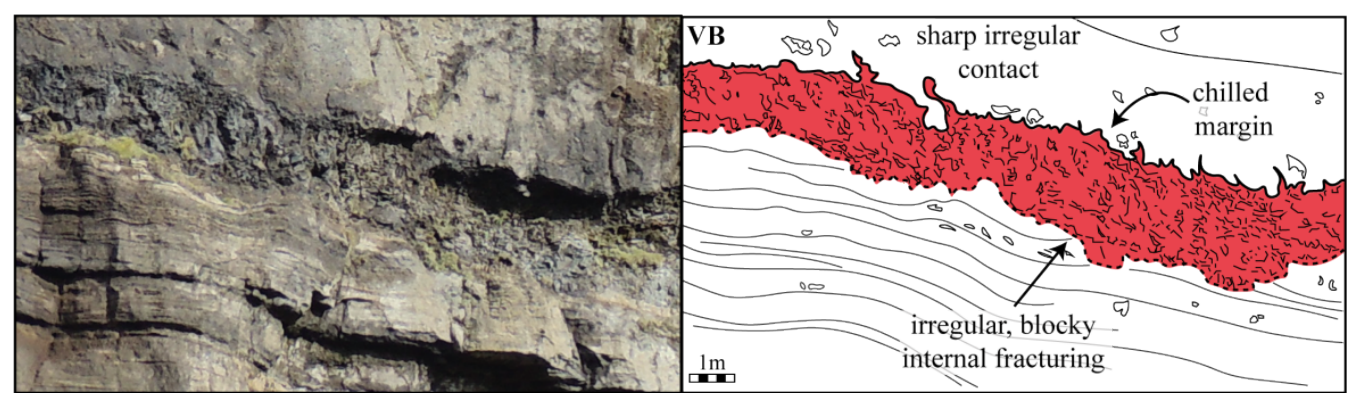

d.

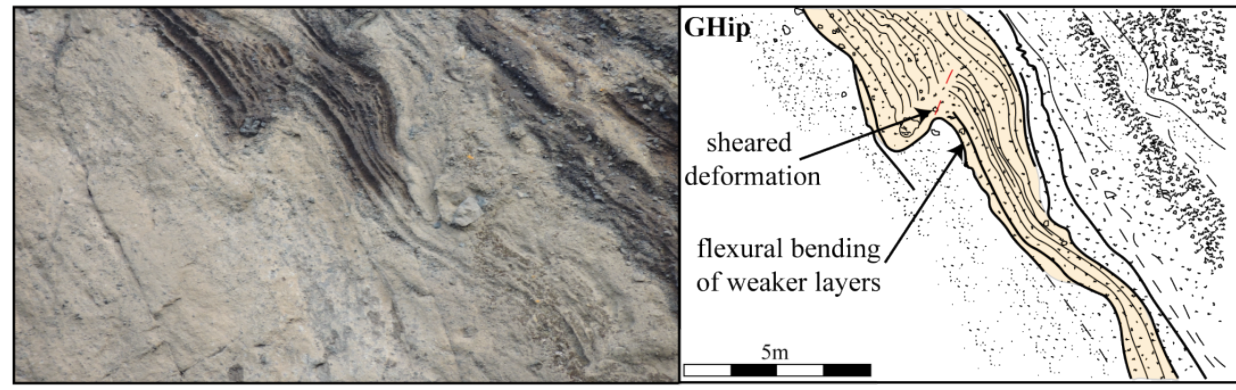

e.
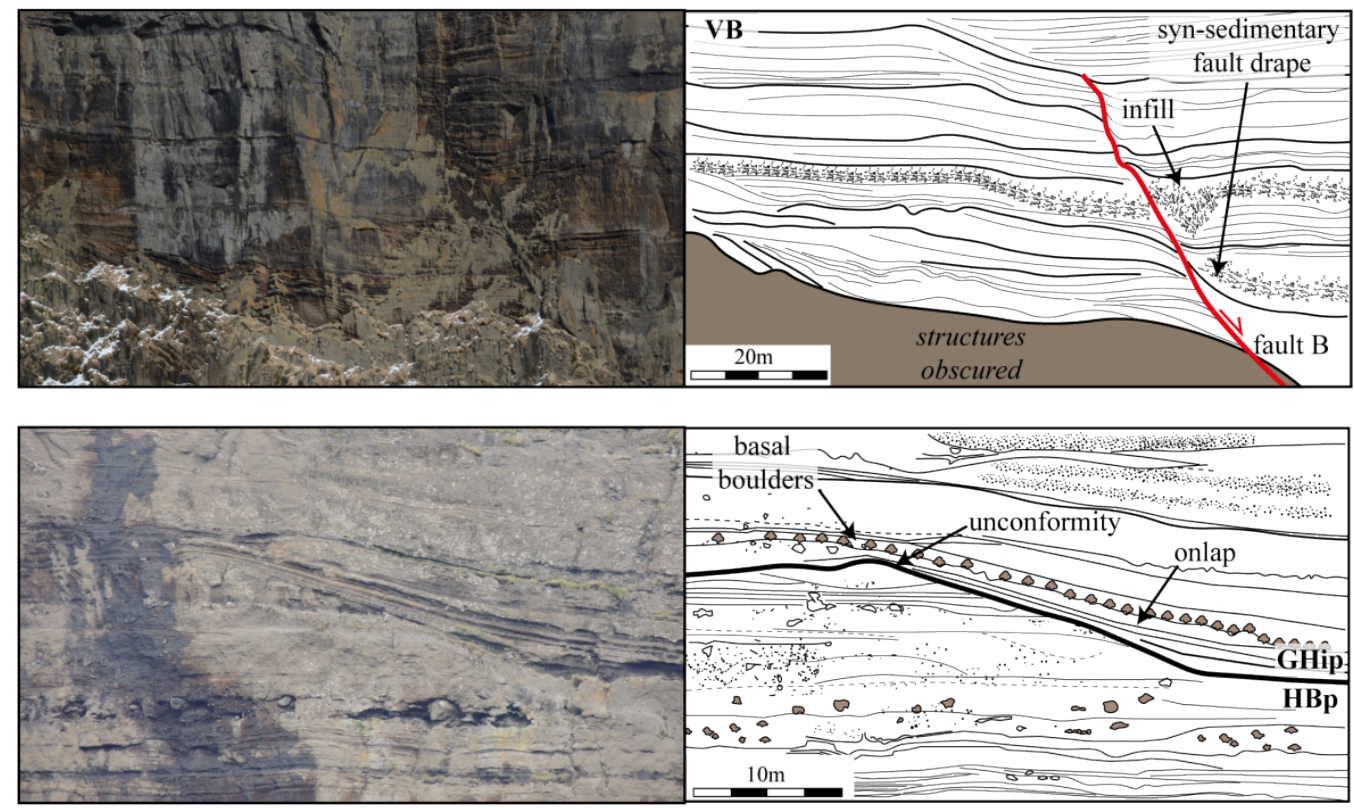

This article is protected by copyright. All rights reserved 


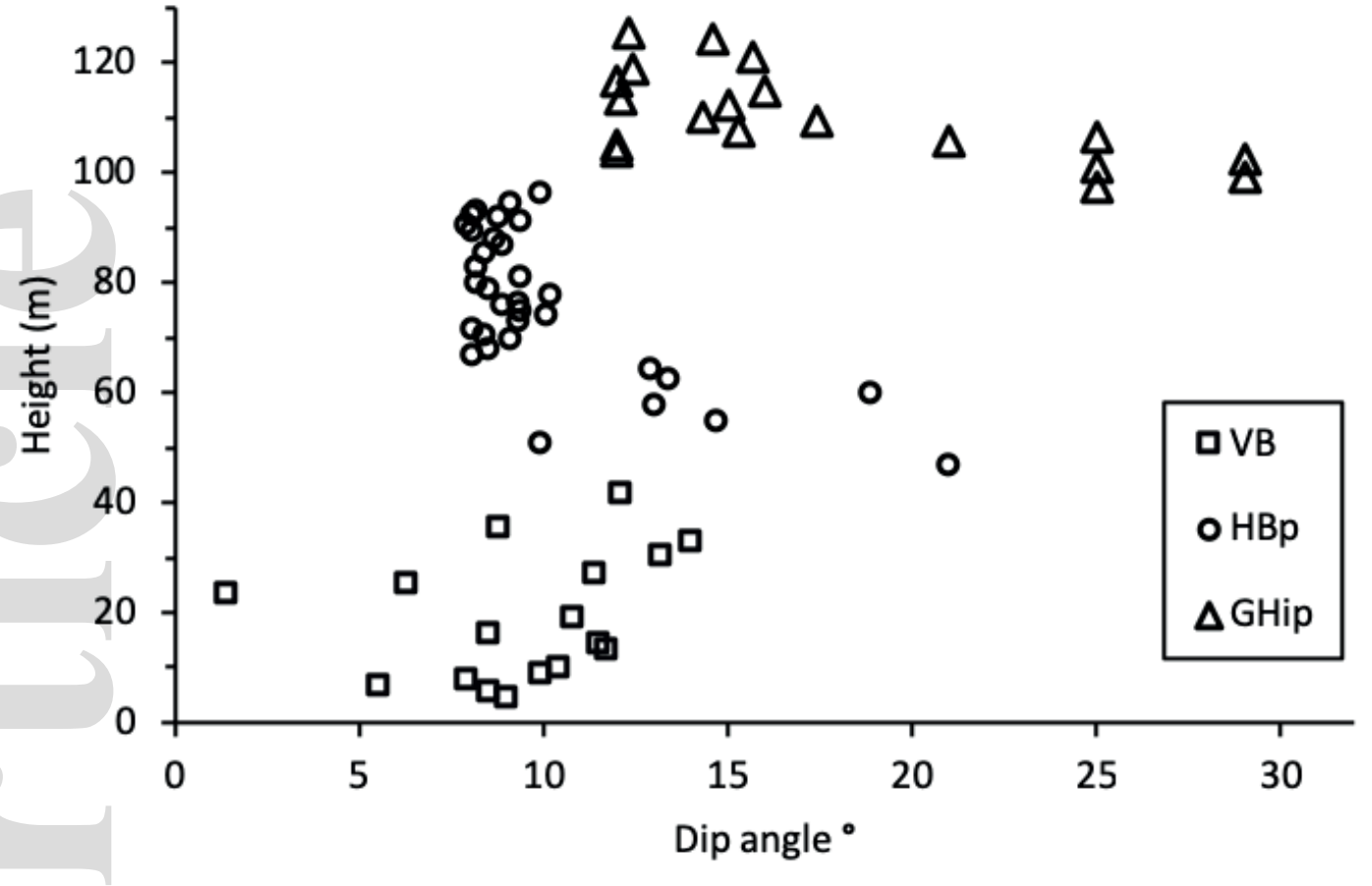

This article is protected by copyright. All rights reserved 


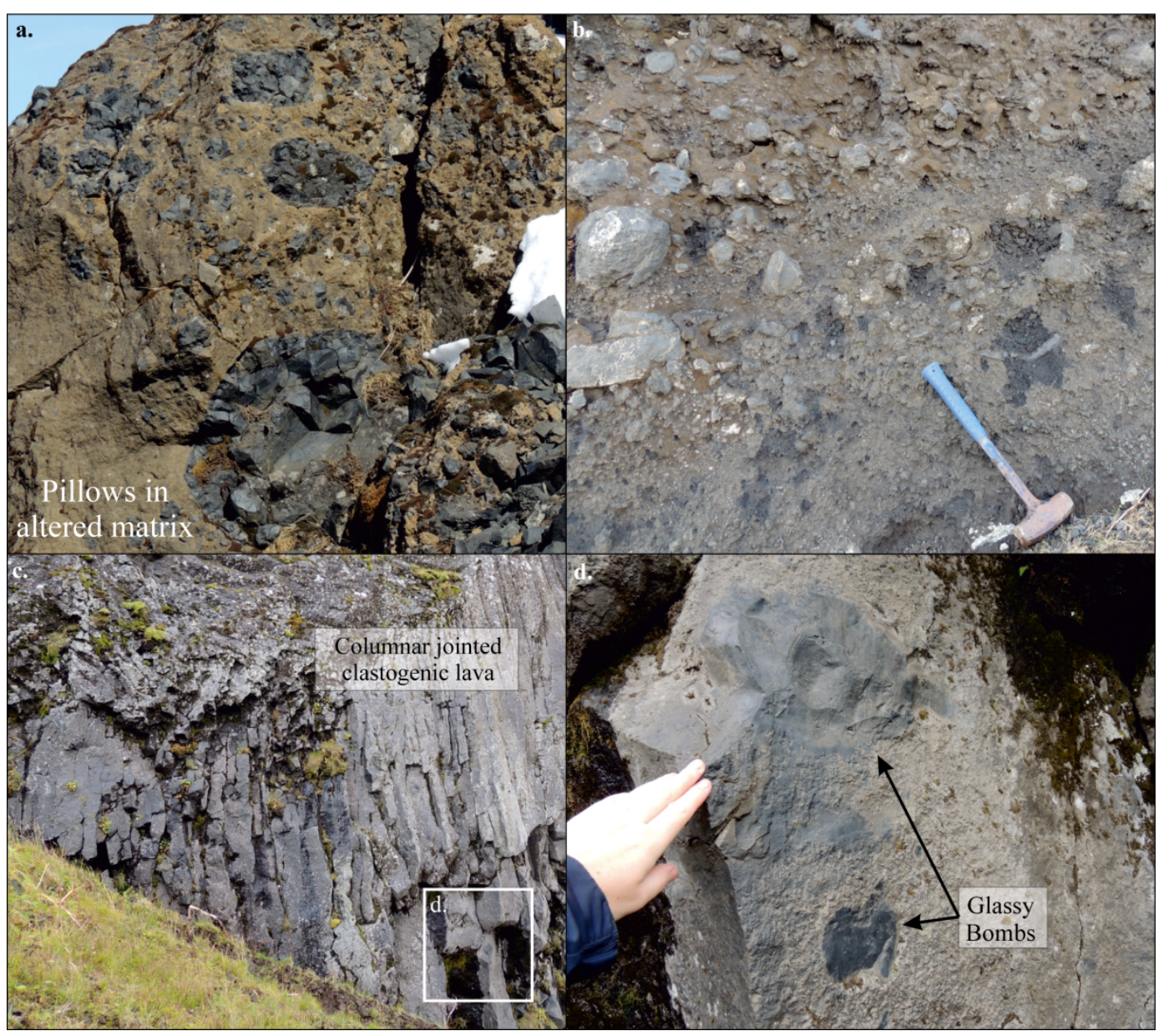

bre_12415_f5.png 
a. Subaqueous phase

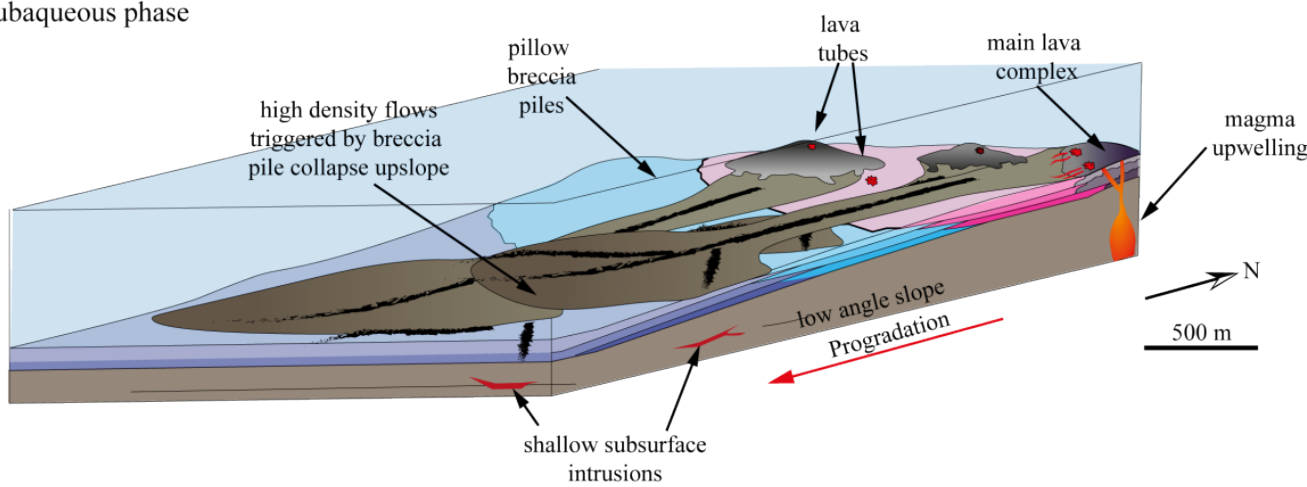

b. Emergence

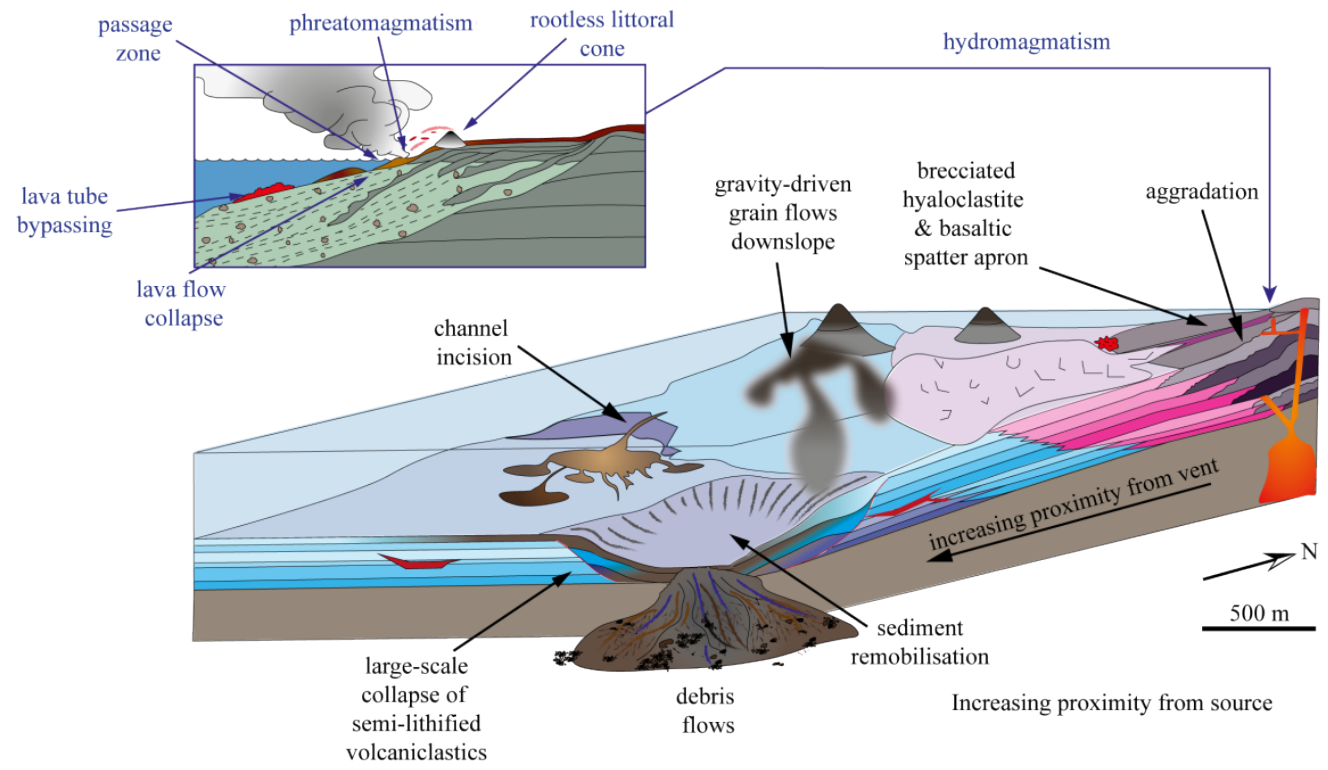

c. Subaerial

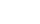

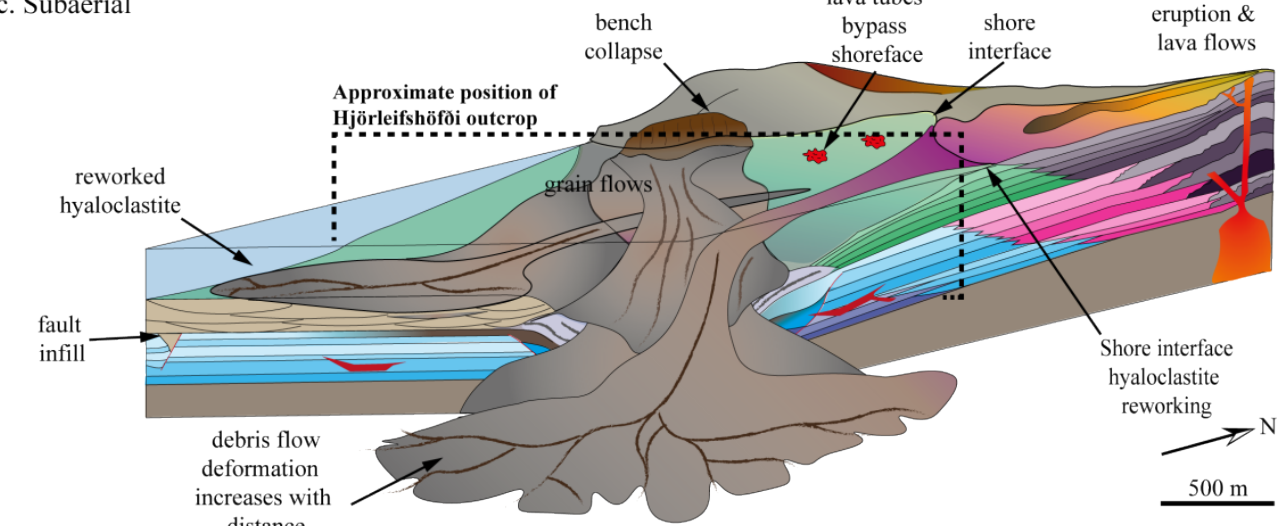

bre_12415_f6.png 


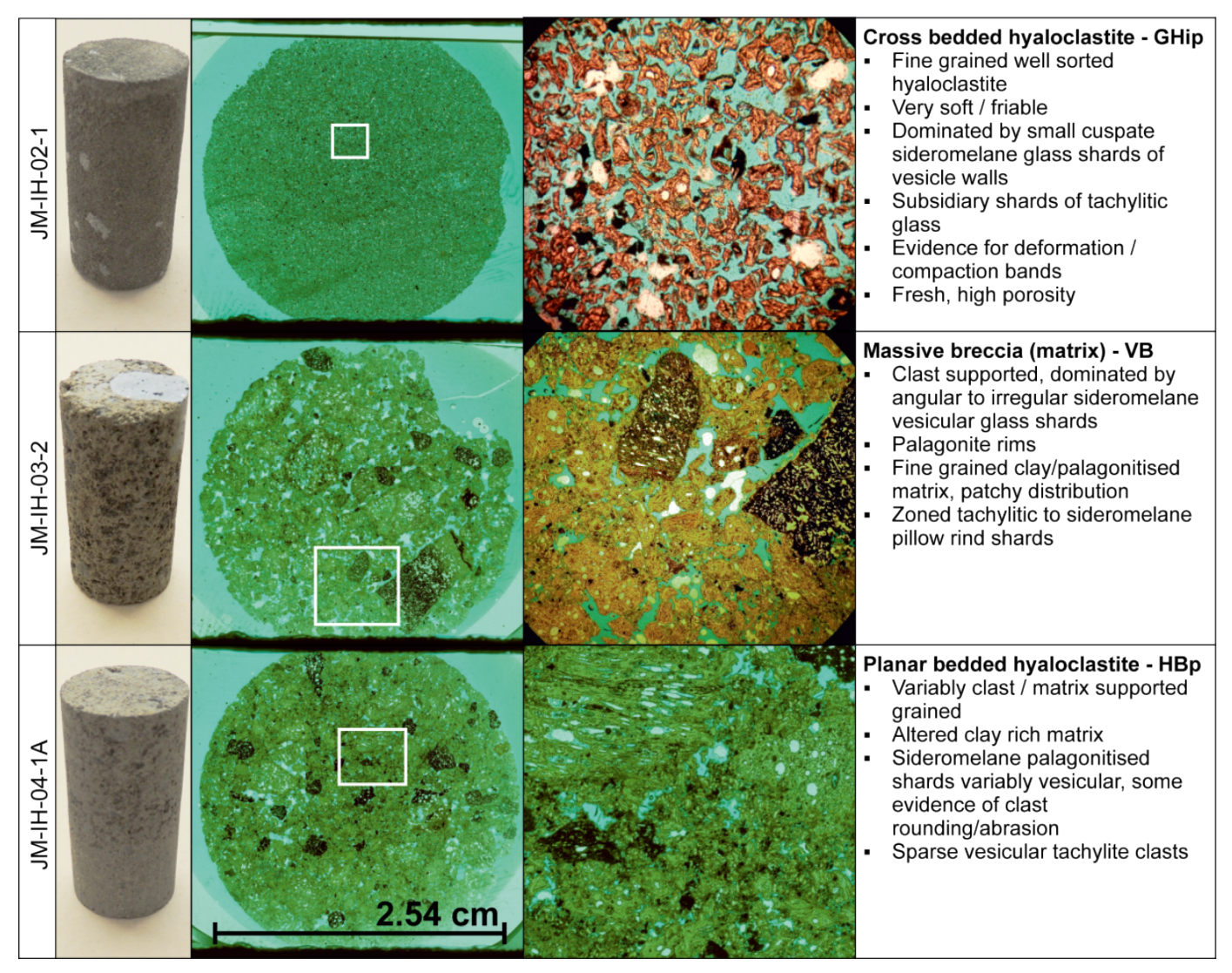

bre_12415_f7.png 


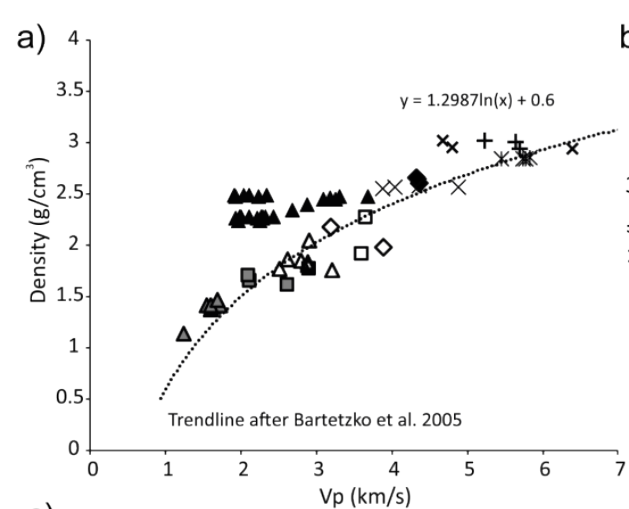

c)
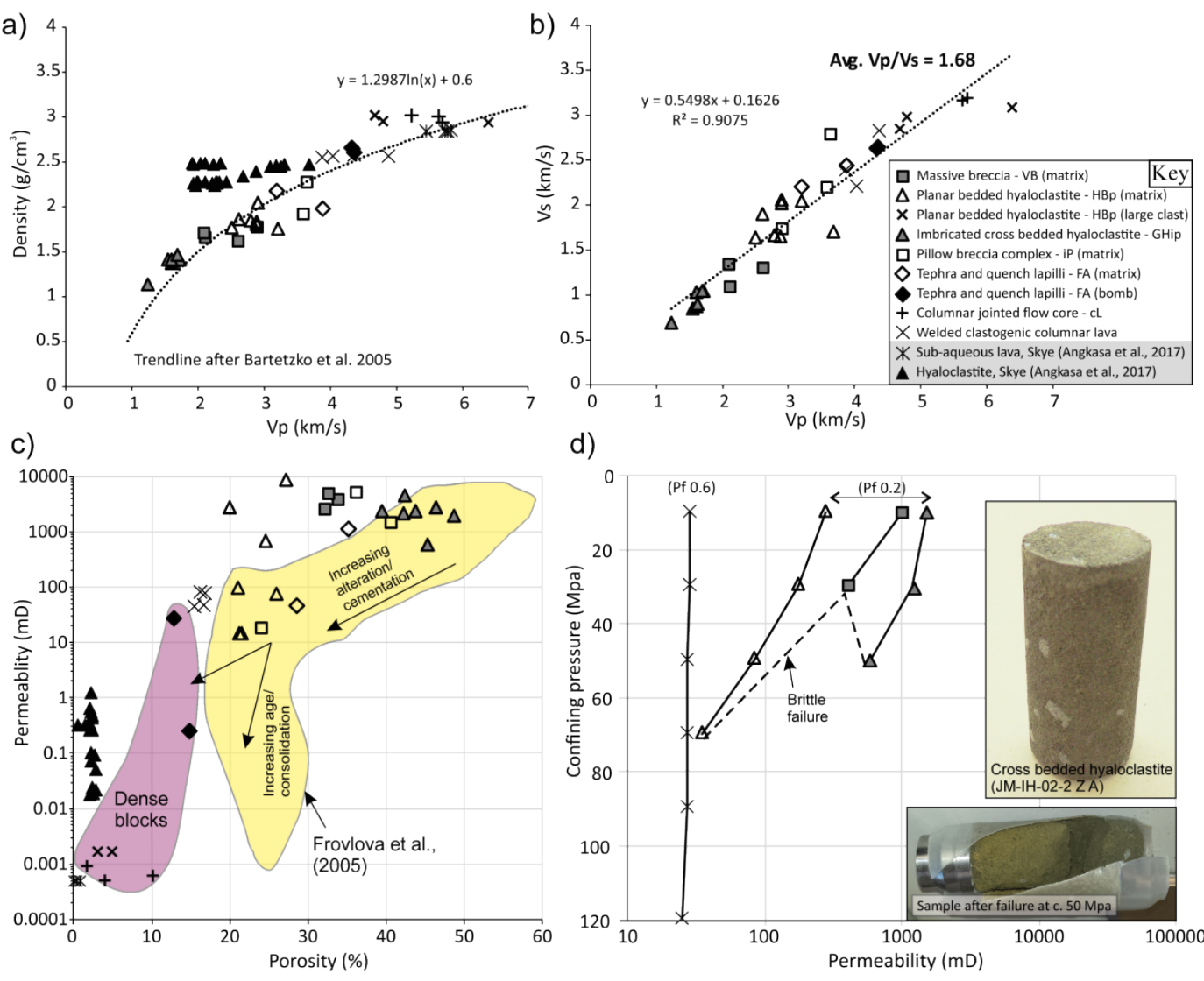

d)

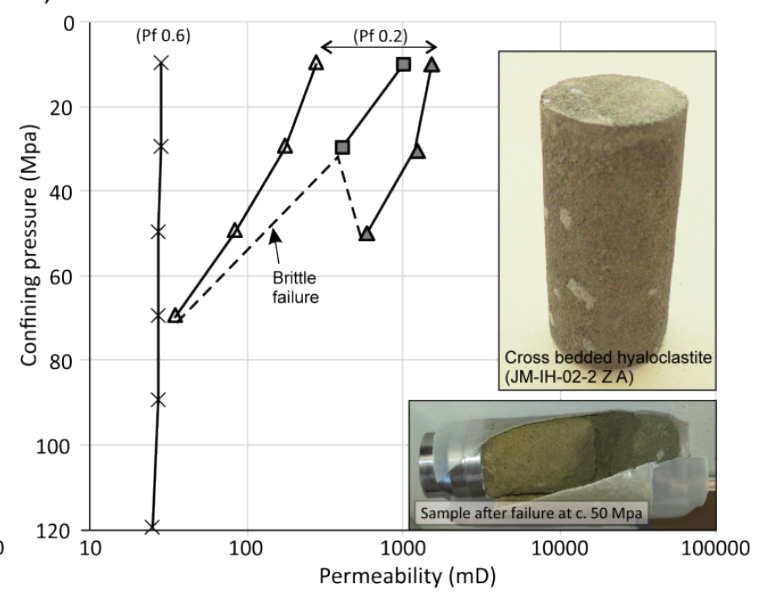

bre_12415_f8.png 
a. Simplified velocity model

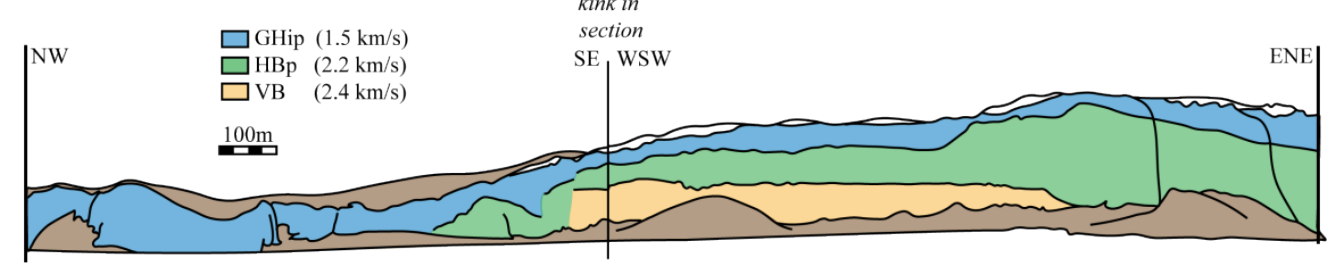

b. Detailed P-Wave velocity model
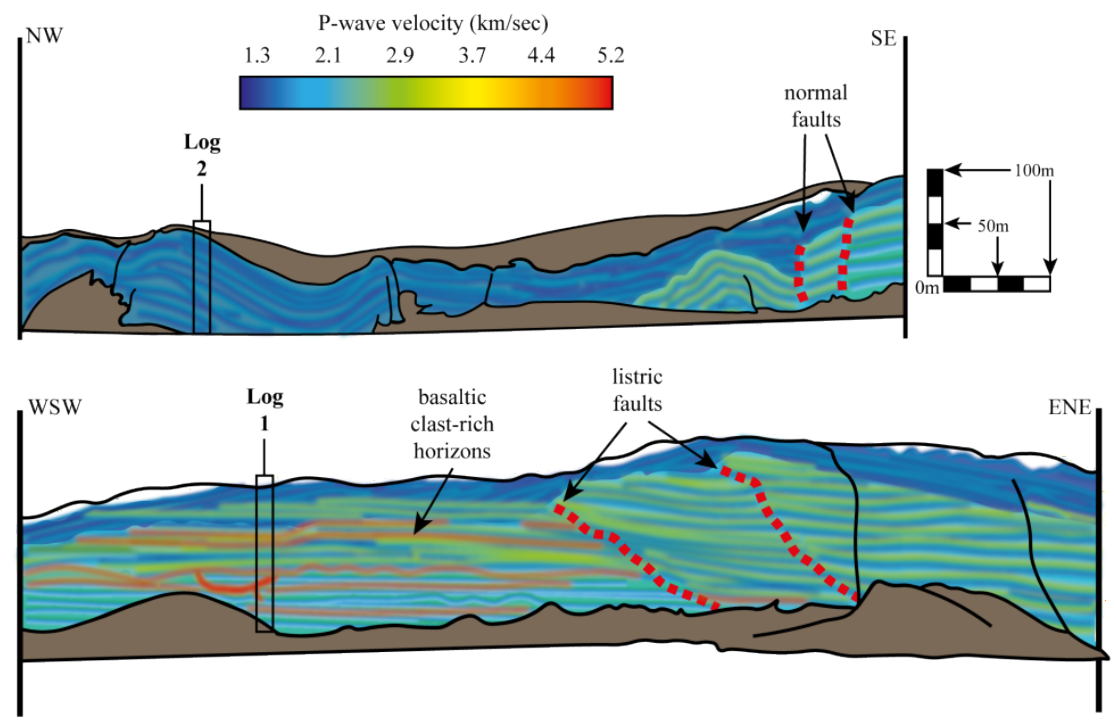

bre_12415_f9.png 
a. Simplified porosity model

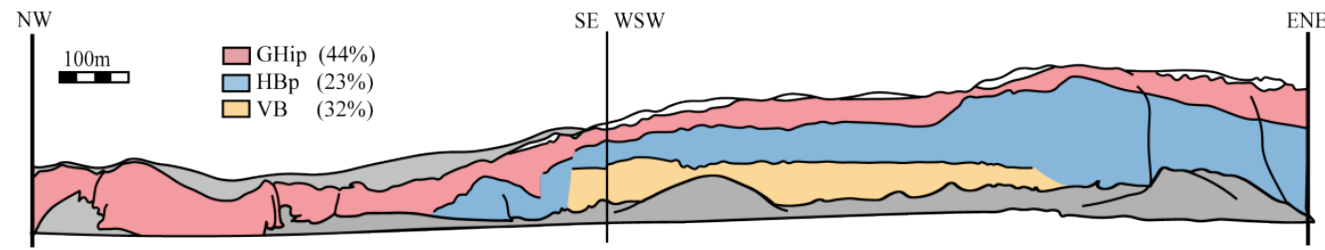

b. Detailed porosity model
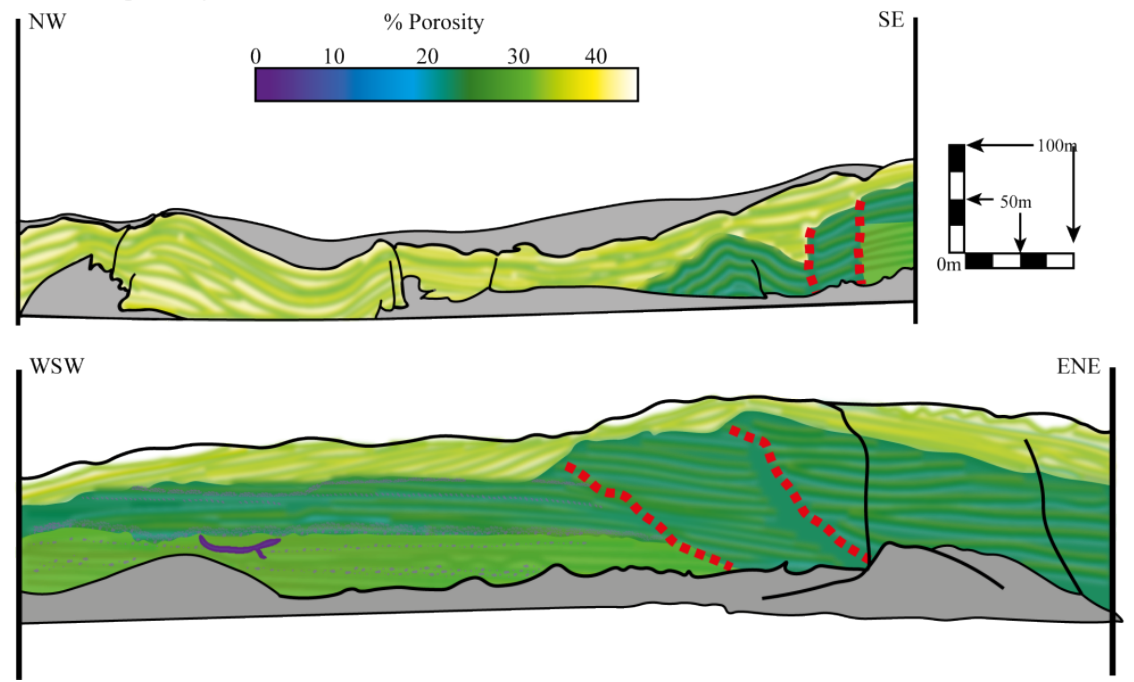

bre_12415_f10.png 


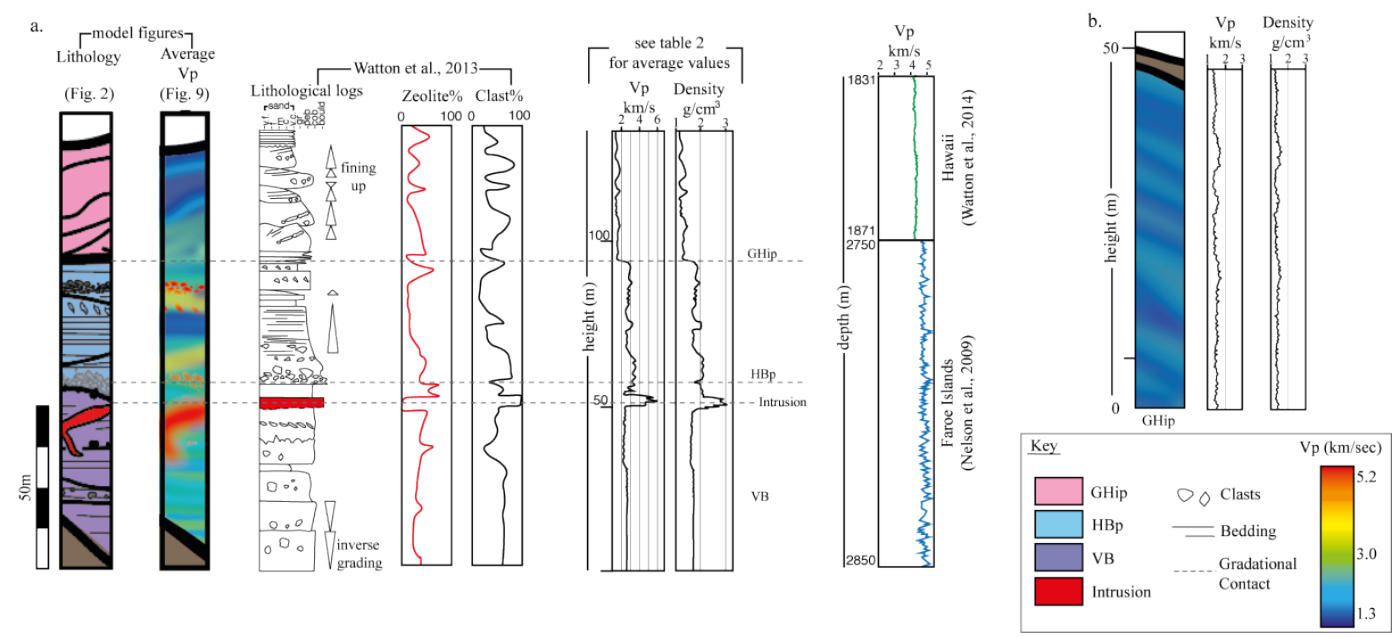

bre_12415_f11.png 